\title{
Lithic Technology and Origin of the Stone Raw Material from the Guenfouda Cave (Jerada Province, Eastern Morocco)
}

\author{
Mohamed Souhir ${ }^{1 *}$, Sergio Almisas Cruz $^{2}$, Hassan Aouraghe ${ }^{1}$, Hicham Mhamdi ${ }^{1}$ \\ 1 Faculté des Sciences, Département de Géologie, Université Mohamed Premier, Oujda, Marocco \\ ${ }^{2}$ Faculté de Philosophie et des Lettres, Département d'Histoire, Géographie et Philosophie, Université Cadis, \\ Espagne \\ * Corresponding author's email: m.souhir@ump.ac.ma
}

\begin{abstract}
The Guenfouda cave is located $30 \mathrm{~km}$ south of the city of Oujda in the Jbel Metssila belonging to the Oujda Mountains. It was recognized as a site of archaeological interest in 2003. Excavations are scheduled every year, and important archaeological material (lithic, faunal and human) has been brought to light. A first study on the lithic industry was carried out by S. Almisas and M. Souhir [2018] under the title of "New studies on the lithic industry of the Neolithic deposits of the Oujda Mountains. Raw material and technology" [Reg.03 "Upper Pleistocene and Holocene cognitive complexity \& archaeogenetics in North Africa" 15th PANAF Conférence, Rabat 2018]. The study is based on technological techniques, the typology of cut products and also on the origin of the raw material used. The lithic industry is abundant, well preserved in all levels and phases of the operating chain are present, indicating debitage in situ in the cave. The artefacts are brought back to the Neolithic for the upper levels, then to the final Upper Paleolithic (or Epipaleolithic) for the lower levels, marked by a change in culture with the appearance of back-to-body lamellae. The first analyses of the raw material used by prehistoric man in this cave, in particular the flint, generally comes from the Swimina area, located to the south of the Oued El Hay basin (Ain Béni Mathar). The limestones come from the surroundings of the mountains of 'Oujda, plains and wadis. As for the basalt, it comes from an ancient Quaternary volcano located near the cave at the top of Jebel Metssila. In turn, quartzites, phtanites, silicified green schist and tuffite, they come from the Paleozoic buttonholes of Glib Naam and jbel boussofane (Province of Jerada). Given the information above, it appears that the man from Guenfouda may have used various rocks for the manufacturing of tools, and would have traveled distances of up to $60 \mathrm{~km}$ in radius to stock up on raw material, especially flint.
\end{abstract}

Keywords: Guenfouda, Prehistoric cave, Oujda mountains, Eastern Morocco, Neolithic, Upper Paleolithic, raw material origin.

\section{INTRODUCTION}

The cultural attributions proposed for the archeogeology of the Guenfouda cave are mainly based on the identification of the lithic industry, with the exception of layer 0 , of which the ceramic furniture is the main diagnostic element. However, before presenting the lithic industries, it seems important to briefly recall the main arguments which lead us to consider that this industry may have been brought or produced on the cave by prehistoric men. The interest in studying this deposit, currently being excavated by Hassan Aouraghe's team (Mohamed I University of Oujda), comes from its archaeological richness, highlighted by the documentation of archaeological products from 2004 - pottery, bone industry, lithic industry, polished products, hammers, etc. [Aouraghe et al., 2008, 2010, 2014] and its proximity to other deposits such as Rhafas, El Heriga or Abri Rhirane. Therefore, the objective of this study was to place this site in its regional context and to examine the nature and the origin of the stone raw materials used. 
The rocks used for the manufacturing of tools by prehistoric men in the cave of Guenfouda are very varied, and appear in the form of volcanic, metamorphic and sedimentary rocks, which shows the level of mastery of the quality of materials by these manufacturers prehistoric.

In the studied area, the main rocks used by this prehistoric population belonged to almost all geological eras:

- For the Paleozoic, there are quartzites; phtanites, silicified green schists (sedimentary rocks metamorphosed in the facies of green schists), tuffites (volcano-sedimentary rock) and dacites (effusive rock).

- For the Mesozoic rocks, we find flint, chalcedony of Trias (of vein origin in dolorites), lower Jurassic flint and Aalino-Bajocian limestone.

- For the Cenozoic rocks, we find the Basalts, the chalcedony of oued el Hay of the Quaternary.

\section{Location and history of the research at the site}

The Guenfouda cave - or Ghar Z'bouj - is located in the northern part of the Oujda Mountains, in the Moroccan Oriental (Fig. 1). The cave is located $30 \mathrm{~km}$ southwest of the city of Oujda and $6 \mathrm{~km}$ from the village of Guenfouda, in the Douar of Aït Bou Said in Metssila - Ben Yala, a few kilometers from the Moroccan-Algerian border. Located at an altitude of $930 \mathrm{~m}$ (Lambert coordinates: $\mathrm{X}=810.20$ and $\mathrm{Y}=440.95$ ), the mouth faces south west, towards a valley crossed by tributaries of Oued Isly.

The cave takes the form of a gallery with two chambers separated by a stalagmitic column. The right chamber, located towards the $\mathrm{NW}$, is larger than the left chamber. It is approximately $6 \mathrm{~m}$ in length and $3.5 \mathrm{~m}$ in width. The left chamber is oriented towards SW and is approximately $3.5 \mathrm{~m}$ in length and $2.5 \mathrm{~m}$ in width. This cavity is formed on a unit of oolitic limestone and dolomitic Aaleno-Bajocian age (171.6 million years) deposited in a marine platform that characterizes Jebel Metssila and all the Oujda Mountains. It should be noted that there are numerous basalt outcrops in the vicinity of the cave, the result of plio-Quaternary volcanic activity [Aouraghe et al., 2008, 2010, 2014].

Excavation of this deposit began in 2004 with the opening of two zones, one at the entrance and the other inside, near a stalagmitic pillar (Figure 2).

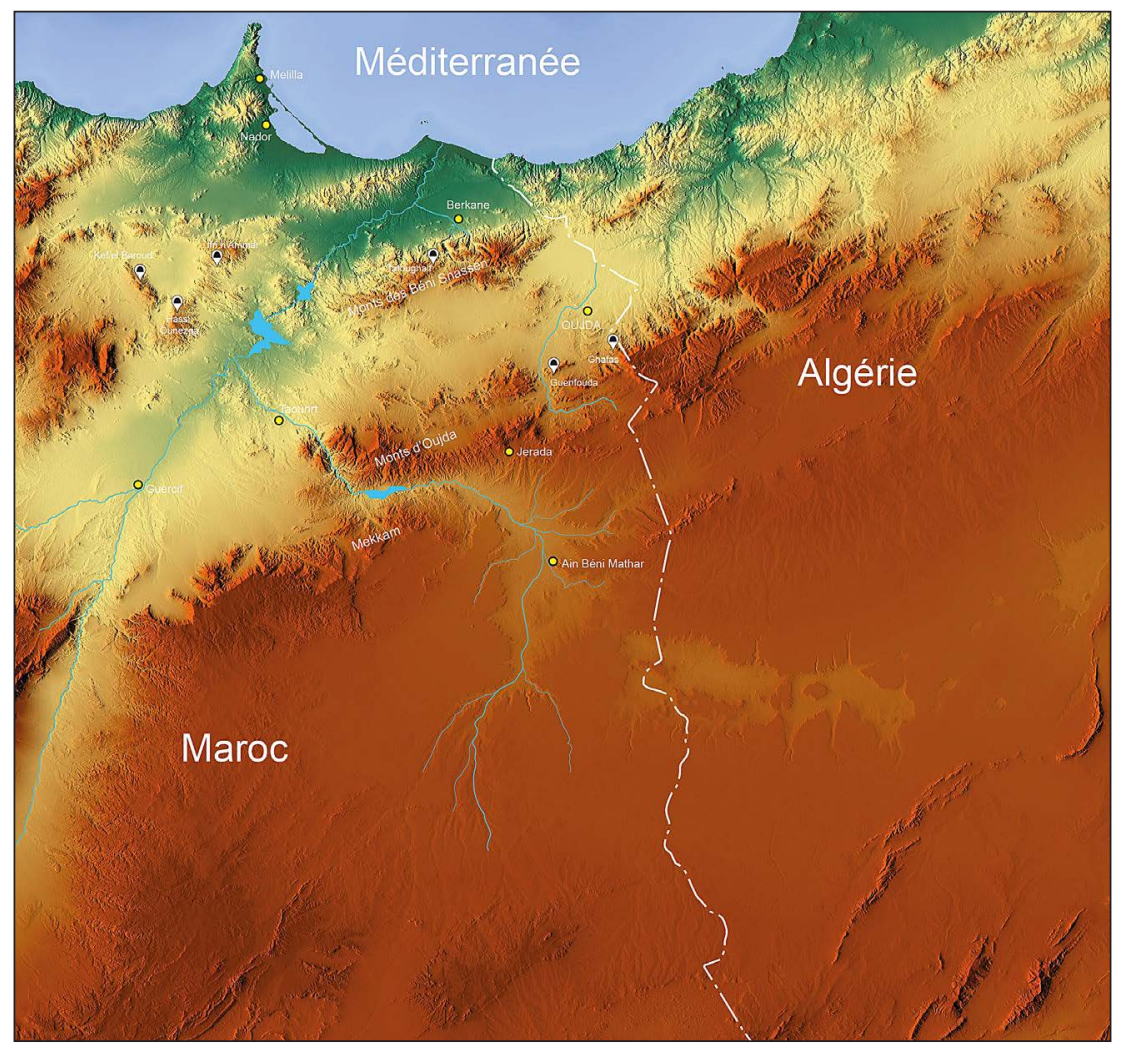

Figure 1. Location of the deposit and general view 


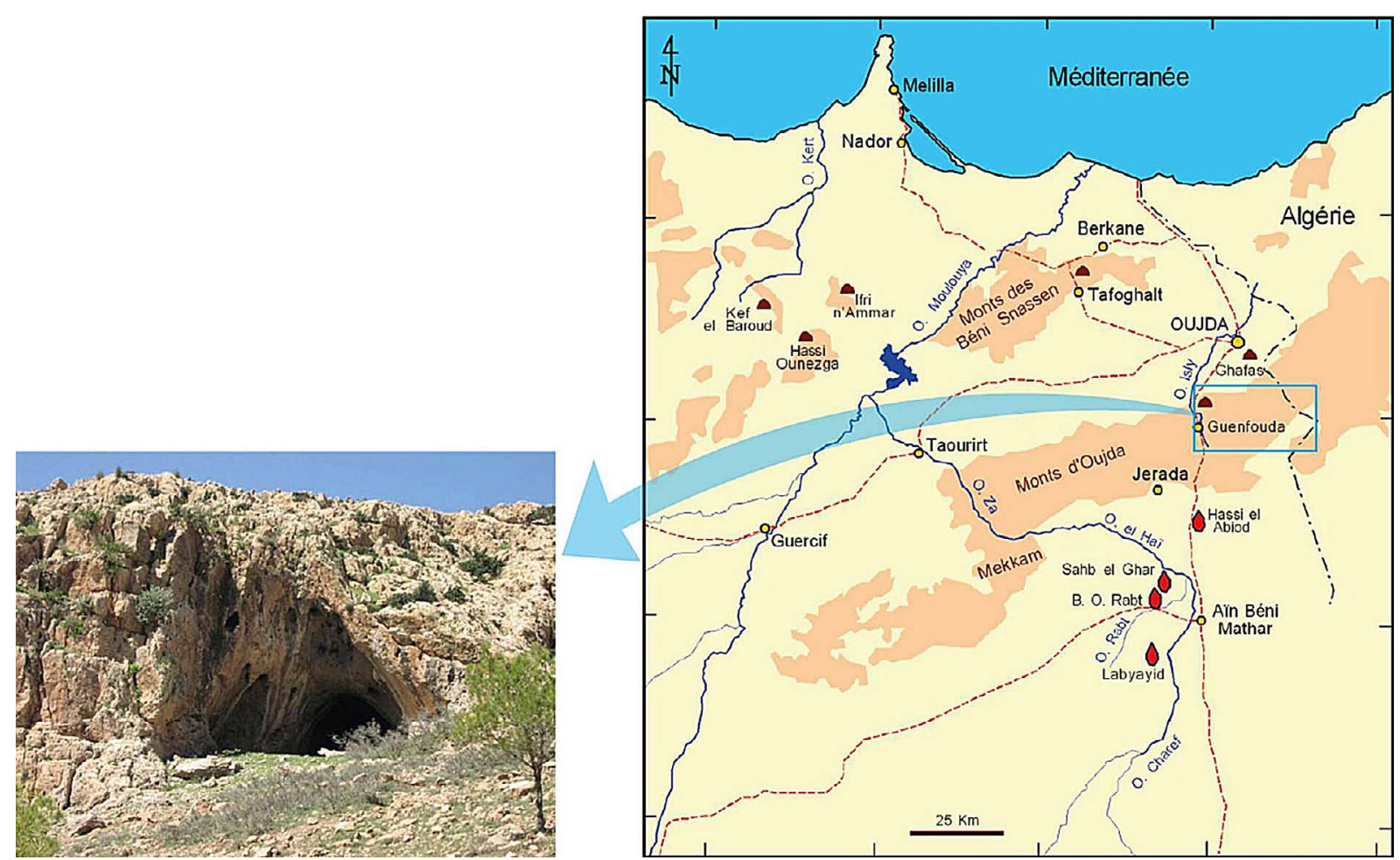

Figure 2. Site map [Aourague et al., 2014]

\section{Stratigraphy}

According to the tomographic survey carried out by Pr D. Khattach, FSO, Oujda who used geophysical methods, the filling of the cave is deep and can reach 2 to $5 \mathrm{~m}$ on the edges of the cave, as shown below.

The superficial layer is generally composed of ashy levels mixed by heated stones, rich in archaeological material.

The stratigraphy of this site reflects a welldefined archaeological sequence, composed of:

- Layer C 0 (Roof of the sequence), rich in metal object and pottery

- Layer $\mathrm{C} 1$ which is subdivided into $\mathrm{C} 1 \mathrm{a}$ and $\mathrm{C} 1 \mathrm{~b}$

- Layer C2 (the basis of the sequencing)
The sediment of layer $\mathrm{C} 1$ is of the calcareous aggregate and powdery silt type. Granulometric analysis has shown the dominance of the fine siltclay fraction and wood ash which is the result of human activity. This type of fine and ashy sediment is not exceptional in the Maghrebian Neolithic [Lubell, 2004]; it is associated with aeolian formation. Layer C2 is characterized by a lithic unit from the Middle and Upper Paleolithic.

\section{C1 Layer}

In spite of the absence of absolute dating, which is discussed below, the $\mathrm{C} 1$ Layer has been associated to a Neolithic phase of the site due to

\section{p<ir.vil!}

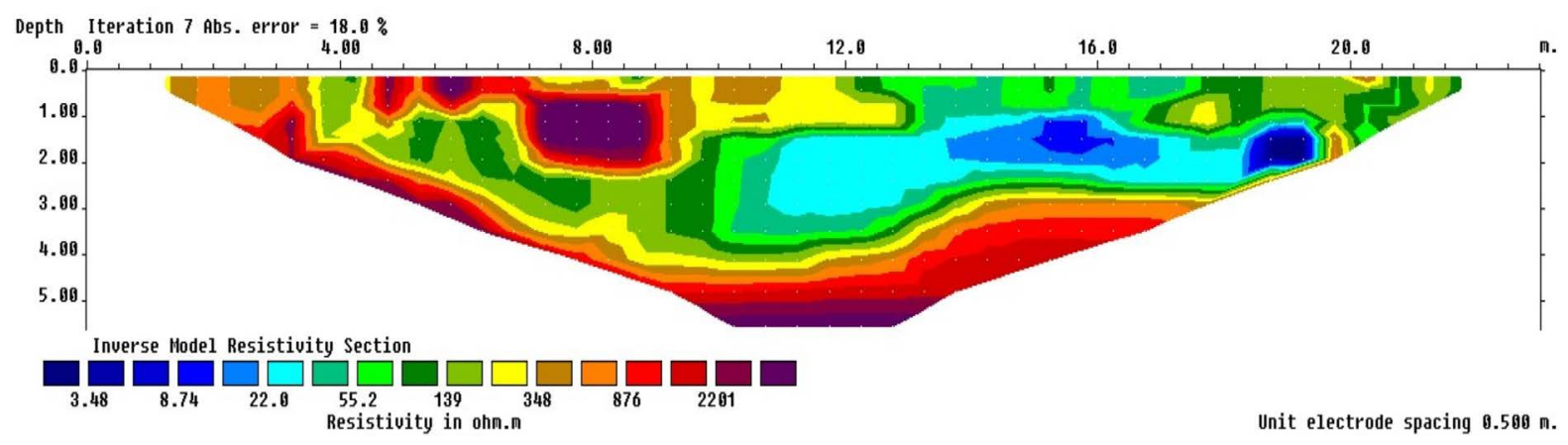

Figure 3. Guenfouda filling: Electrical tomograph [Khattach, Aouraghe 2008] 


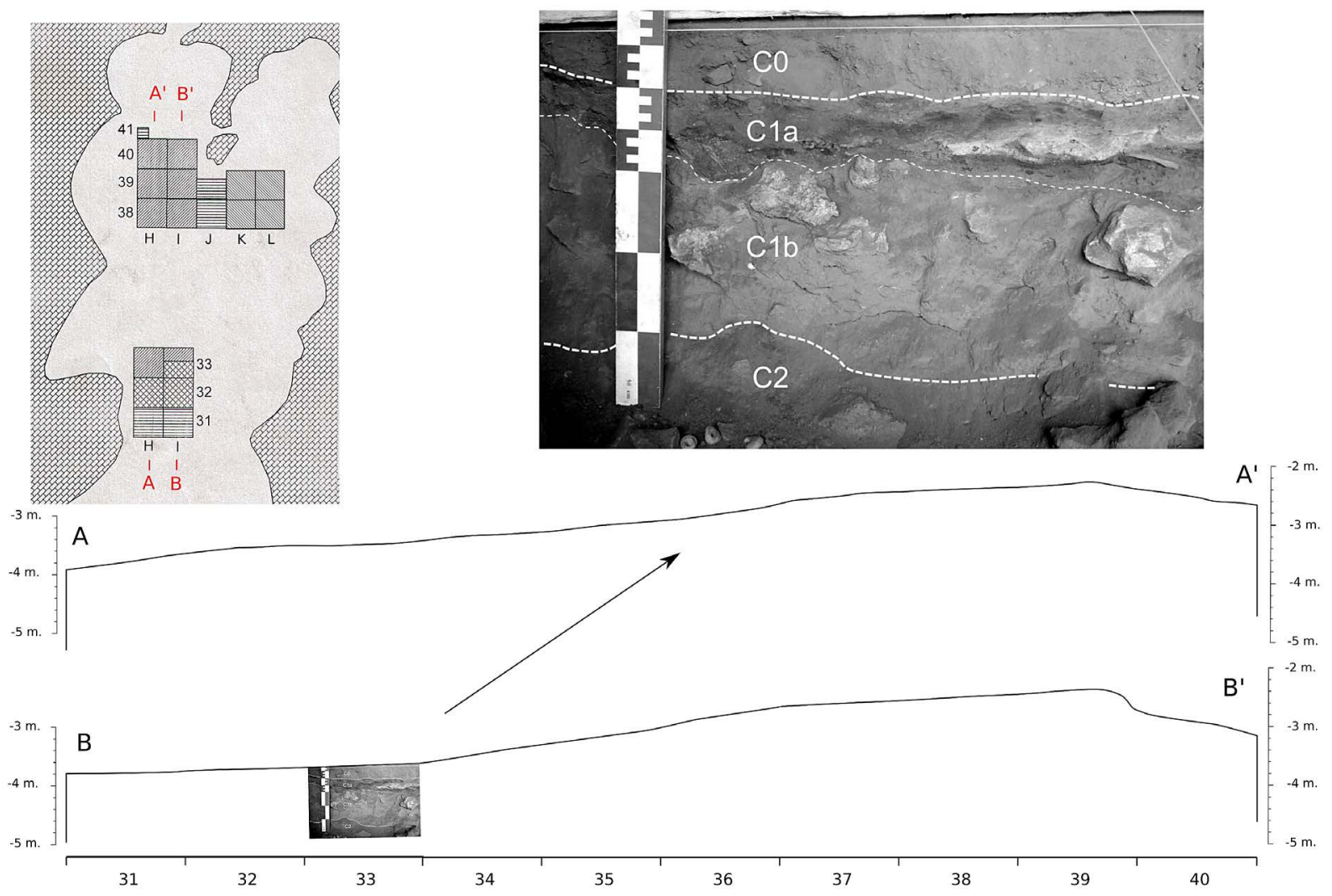

Figure 4. Profile and stratigraphy of Guenfouda [Aourague et al., 2014]

its archaeological remains, characterized by a large lithic assembly as well as fauna and malacofauna remains, fragments of pottery, grinding and stone polishing tools, polished tools, working pottery tools and beads and pieces of ostrich eggs [Aouraghe et al., 2014].

It must be emphasized that this $\mathrm{C} 1$ layer is altered in its upper part by the layer 0 , which insert modern products like some metal objects and pottery localized in a few centimeters in the top of the deposits. These stratigraphic alterations, linked to bioturbation and recent human activities, are common in caves with low compact sediments. Nevertheless, the archaeological remains are coherent and do not show the marks of great post-depositional changes.

\section{The $\mathrm{C} 1$ Lithic assemblage}

During the first excavation campaign, the deposit gave a very large lithic industry in all levels; more than 3,900 pieces. The recording, identification and study are based on 2572 pieces of the $\mathrm{C} 1$ layer (except for the I column), principally concentrated in squares 38-39-40 (Fig. 5). For the raw material study, 2572 pieces were analyzed.

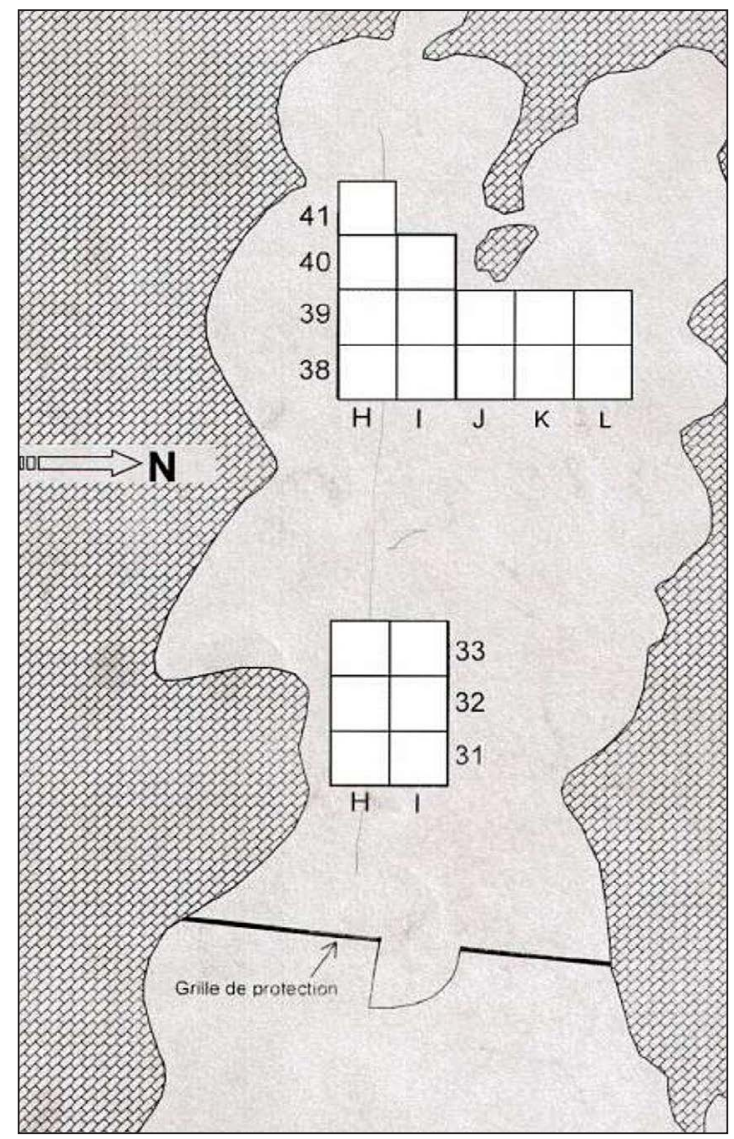

Figure 5. Plan, area and squares excavated from 2004 to 2019 


\section{The techno-typological study}

The lithic ensemble was studied according to the Logic-Analitic System based on the approach of Georges Laplace and developed by the team of Eudald Carbonell [Carbonell and Rodríguez, 2002]. In addition, the nomenclature adopted was similar to that proposed in the geology dictionary of A. FAUCAU. The study of the lithic register yielded the following results: the presence of cores or Negative Bases of 1st Generation BN1G (130 pieces), flakes, blades and lamellae Positive Bases BP (1404 pieces), cut waste - ORT (832 pieces) and retouched products - Negative Bases of 2nd Generation BN2G (206 pieces).

The essential use of three types of raw materials was noted: silicified green shale (30.88\%), flint (27.14\%) and chalcedony (23.98\%). Other raw materials identified are in the minority overall: limestone $(4.19 \%)$, basalt $(1.89 \%)$, quartz $(2.9 \%)$, quartzite $(2.43 \%)$, dacite $(0.41 \%)$, sandstone $(0.19 \%)$, limestone $(4.19 \%)$ tuffite $(0.11 \%)$ and phtanite $(0.15 \%)$. Roughly speaking, the lithic ensemble does not mark the process of moving the pieces and has shown a weak patina $(6.53 \%)$ characterized by the colors white-gray and red. The thermal alteration is about $14 \%$ for the lithic unit.

Regarding BN1Gs (cores), they are composed of 30 unipolar cores (U), 45 bipolar cores (B), 38 polyhedral cores (Pol), 3 cores of the beginning of size (DdT), 6 centripetal multipolar cores (CM) and 8 prismatic cores $(\mathrm{P})$. In general, five Indirect Technical Operative Themes (T.O.T.I.) were deduced, which informed us about the different size-strategies. Silicified schist, flint and chalcedony seem to have been favored for all of the cores. These have the same characteristics as the rest of the products with a slight patina (9.17\% in white color) and a temperature change of approximately $12.58 \%$.

While studying the technical characteristics, the presence of striking, non-cortical planes was noticed. The cores are for the most part exhausted and their dimensions are almost less than $4 \mathrm{~cm}$ in length and width (counted as type), microeclat, microeclatlaminar, microlaminar and narrow microlaminar [Bagolini, 1968].

In total, 1404 pieces of the group of positive bases (BP-flakes) was counted, made up as follows: 22 debitage products (BP-D), 88 of semidebitage (BP-SD), 84 lithic products relating to

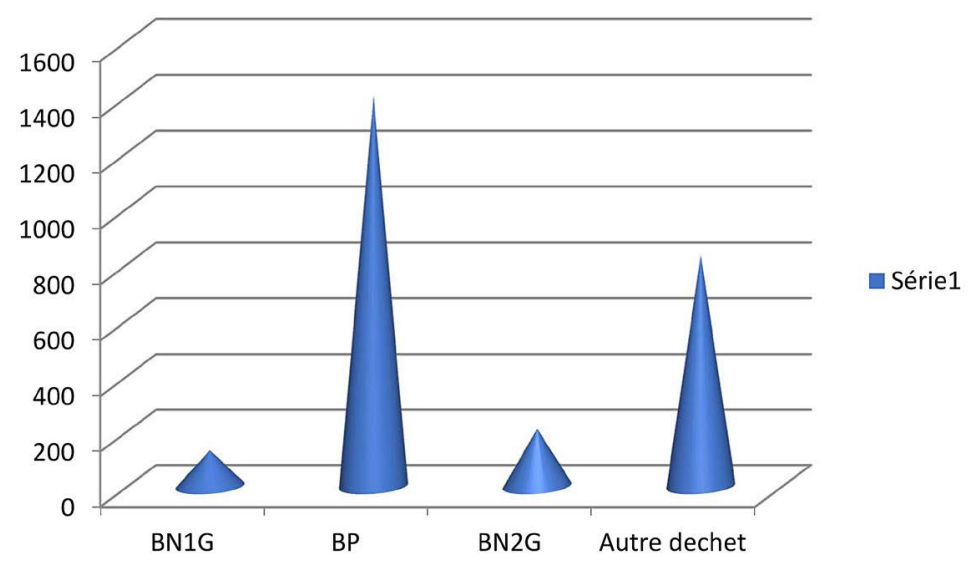

Figure 6. lithic from the Guenfouda cave

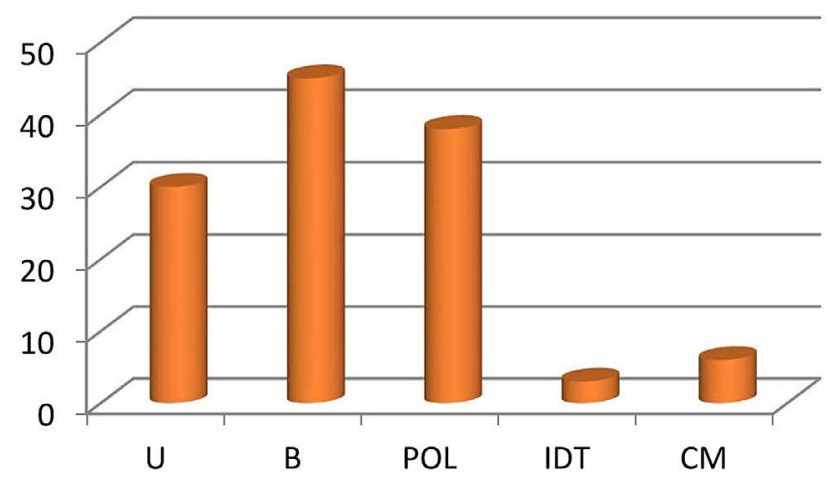

Figure 7. BN1G products (cores) from Guenfouda 


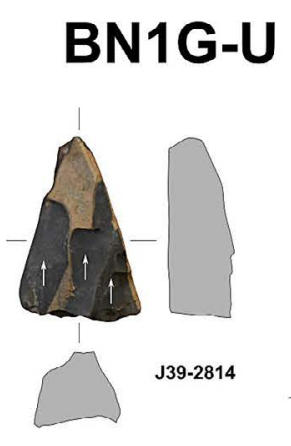

BN1G-B
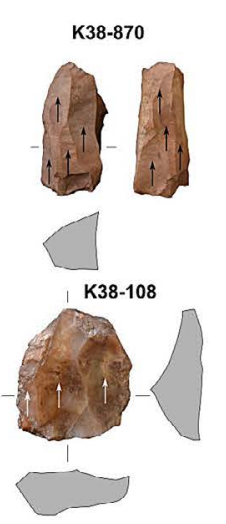
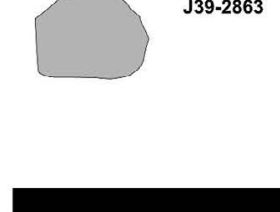

0

\section{BN1G-CM}

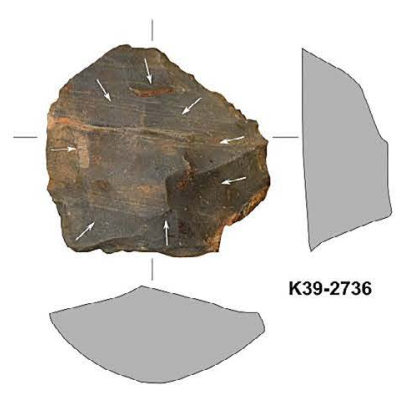

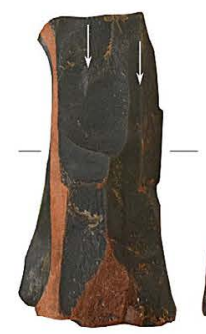
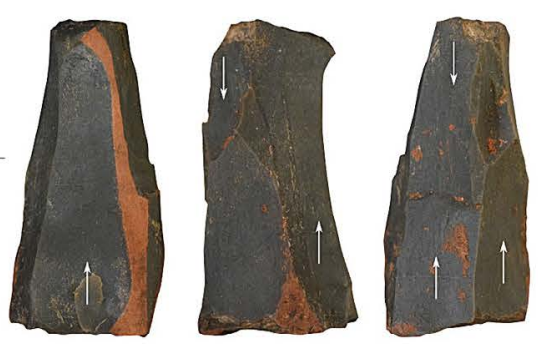

J38-581
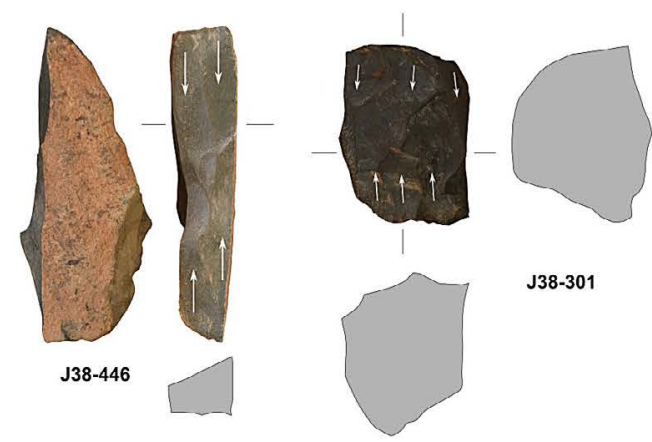

J38-301<smiles>C1CCCCC1</smiles>
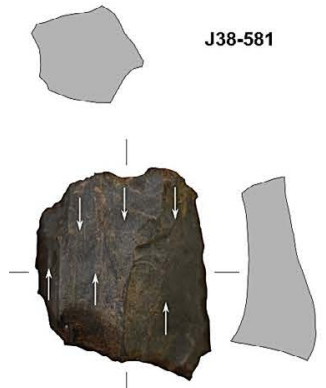

J39-1008
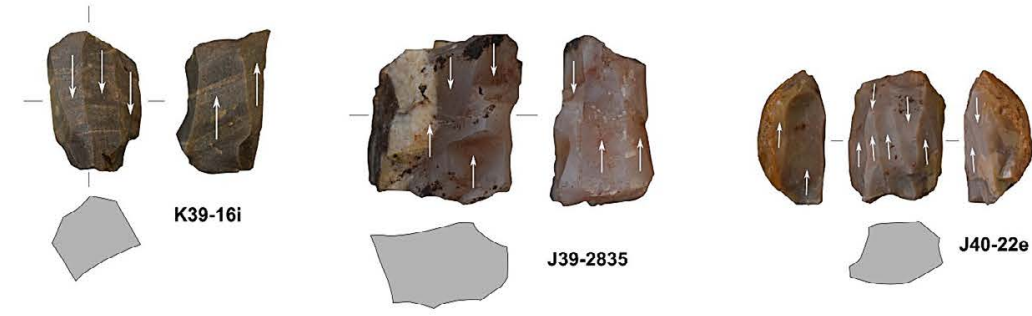

J39-2835

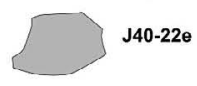

\section{BN1G-P}
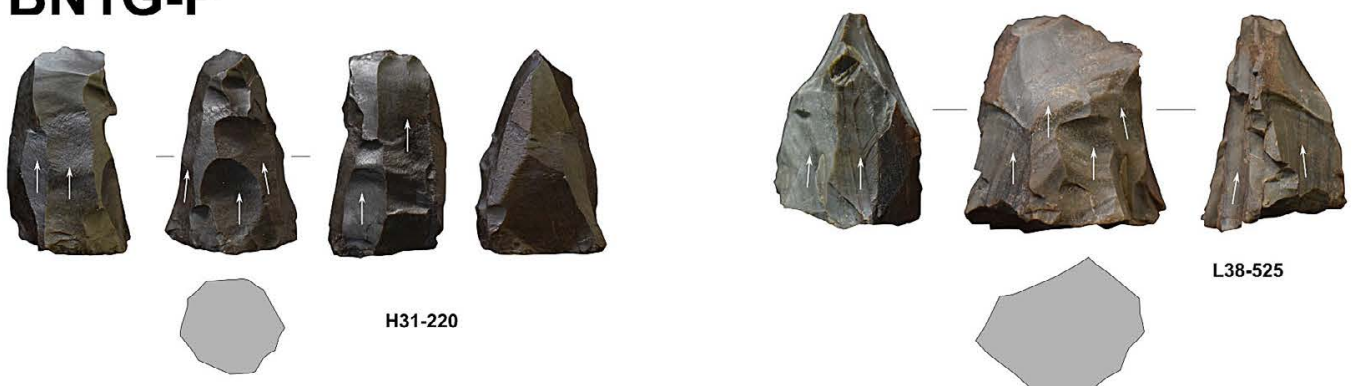

H31-220

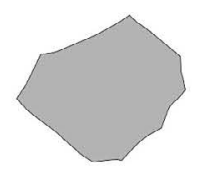

L38-525

BN1G-Pol
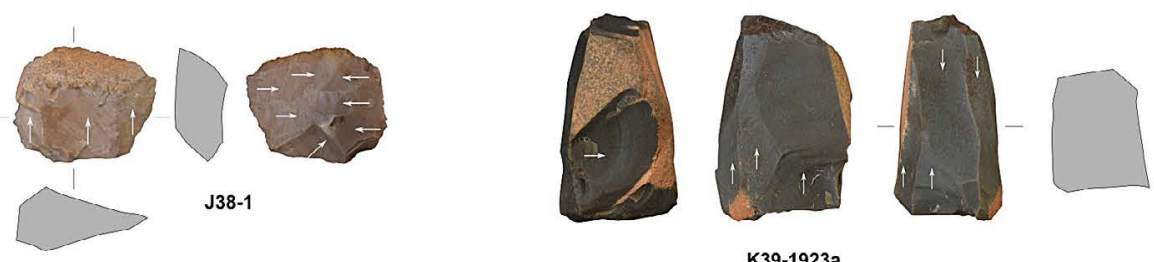

K39-1923a

Figure 8. BN1G products (cores) from Guenfouda (Almisas and Souhir) 


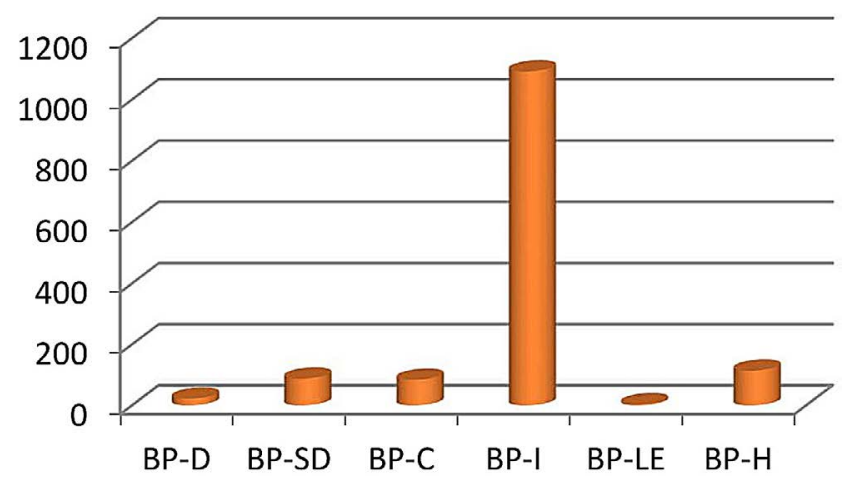

Figure 9. BP products (flakes) from Guenfouda

the preparation of cores (BP-C), 1092 flakes and blades of internal type (BP-I), 4 of Levallois type (BP-LE) and 114 flakes (BP-L).

The present screening and semi debitage products prove that the debitage activity is carried out on site.

The physical characteristics are gathered in the lithic ensemble (physical alteration, thermal alteration, patina...). The raw materials are dominated by flint (33.01\%), chalcedony (29.73\%) and silicified shales $(27.75 \%)$.

For the technical characteristics of BP, the predominance of diffuse bulbs was noted $(66.8 \%)$, which reflects the use of direct percussion or indirect percussion pruning techniques. This size control is consistent with the good presence of the right forms of the ventral side (39.25\%). For conserved heels (982), they are dominated by fences (396 = 40.32\%); follow-up of dropped heels (223 $=22.70 \%)$; cortical $(114=11.60 \%)$; dihedrons $(97$ $=9.87 \%)$; faceted convex $(90=9.16 \%)$; faceted $(61=6.21 \%)$ and punctiform $(1=0.10 \%)$.

For the BP lot, the chips are dominant compared to the blades (approx. 68/32). The Bagolini module (applied to 643 pieces) offers us a majority presence of small and micro modules, with predominance of small lamellae, micro-lamellae, small laminar flakes, micro-flakes, laminars, small flakes and micro-flakes.

The retouched products $(\mathrm{BN} 2 \mathrm{G})$ are well-represented in the lithic set with 206 products. The predominant types are backed-points and blades and notches and denticulates. With a lower proportion, one counts the scrapers, abrupt, chisels, truncations, bipoints with backs, bi-truncations, beaks and blades with truncated backs. These products have similar physical characteristics to the lithic ensemble, and the same for the raw material, dominated by flint, chalcedony and silicified shale Compared to BP, BN2G is cut from a better proportion of laminar products $(70.7 \%)$, mainly BP-Internal (148 supports) and blades (17 products). In BP-Internal, the predominance of diffuse bulbs can be seen (77.4).

Out of 141 preserved heels, the dominance of the dropped heels was documented $(71=50.35 \%)$; in addition to smooth heels $(32=22.68 \%)$; dihedral $(10=7.09 \%)$, faceted convex $(8=6.8 \%)$; faceted heels $(11=7.80 \%)$, cortical heels $(6=$ $4.25 \%)$ and puncture heels $(1=0.70 \%)$.

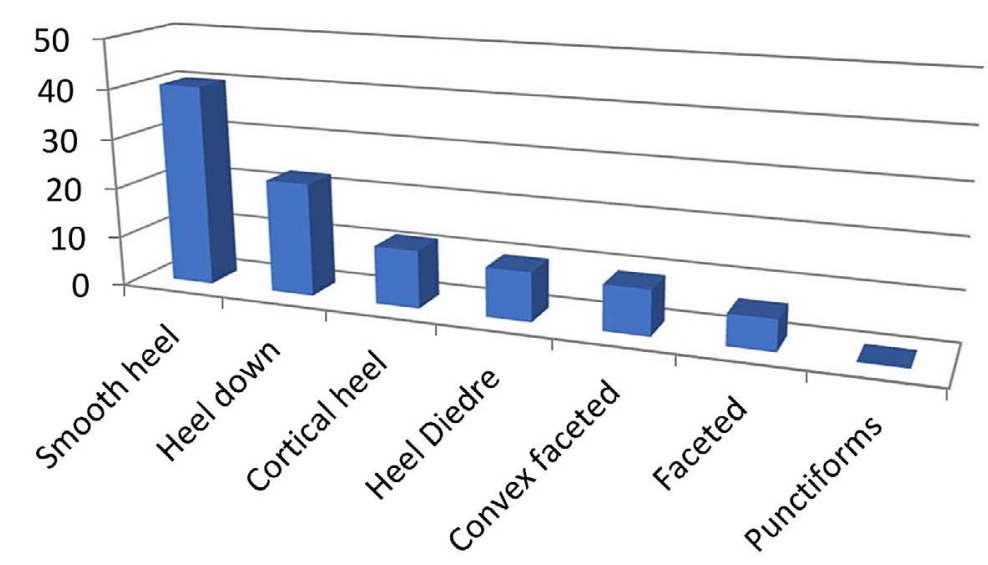

Figure 10. the preserved heels of the Guenfouda BP 


\section{BP-D}
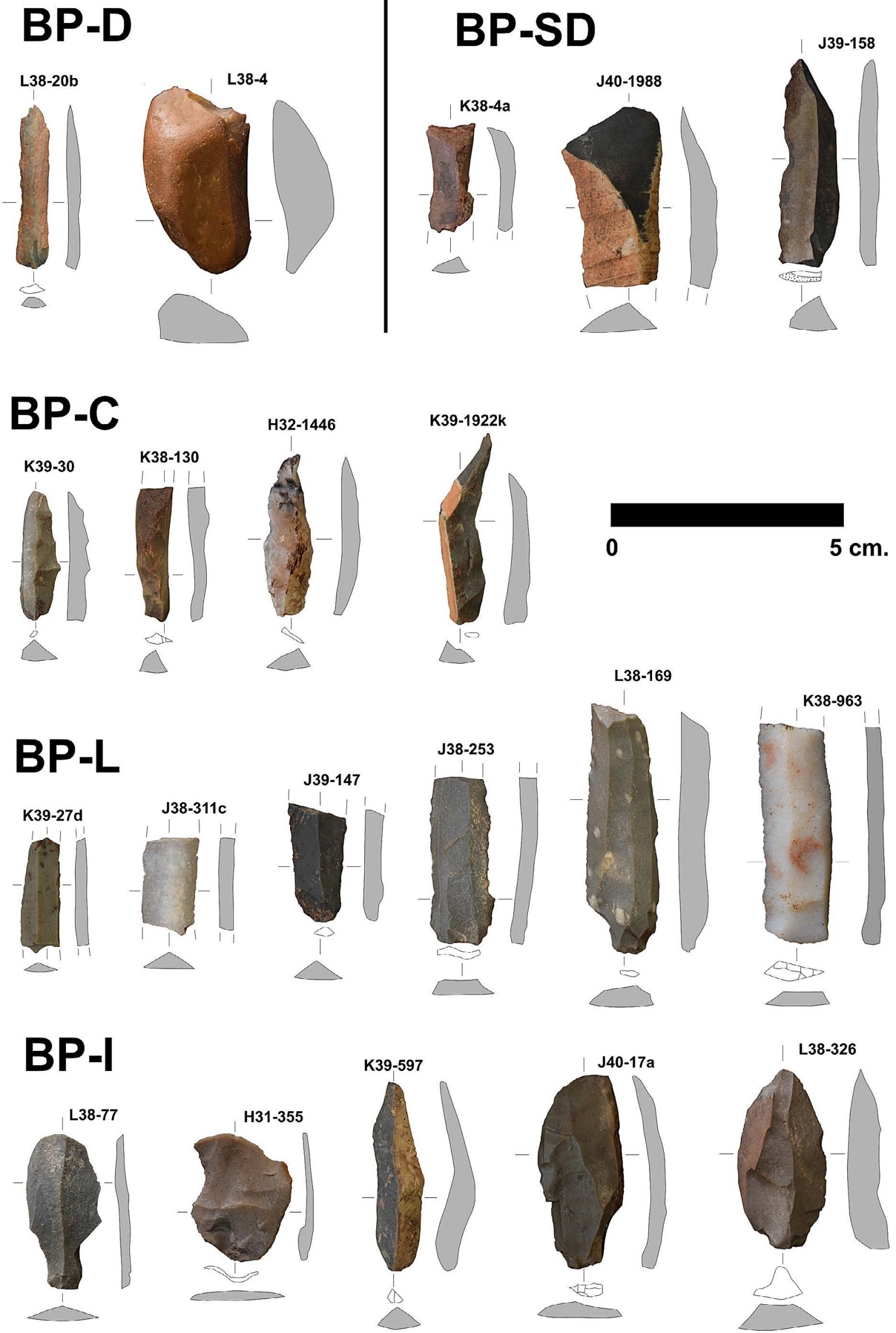

Figure 11. BP products (flakes) from Guenfouda (Almisas and Souhir) 
To conclude, the complete classification of retouched products is as follows:

- 18 scrapers, composed of 7 single front end scrapers (G11), 4 single front end scrapers with lateral retouching (G12), 3 single front fairing scrapers (G311), 2 single front fairing end scrapers (G312) and 2 fairing end scrapers open muzzle (G322).

- 44 denticulates and notches, composed of 2 marginal notches (D11), 26 notches (D21) and 16 denticulates (D23). Some notches and denticulates are associated with other retouching.

- 18 steep, 8 marginal (A1) and 10 deep (A2).

- 11 truncations composed of 4 normal truncations (T21) and 7 obliques (T22).

- 2 beak-truncation $(\mathrm{Bc} 1)$.

- 37 points with backs, composed of 5 points with marginal full back (PD13), 1 point with double marginal back (PD15), 26 points with full back (PD23) and 5 points with double backs (PD25). These backed-points are very homogeneous, with a thickness of $0.2-0.7 \mathrm{~cm}$ and a width of $0.4-1 \mathrm{~cm}$.

- 49 backed-blades, composed of 6 marginal backed-blades (LD11) and 43 deep backedblades (LD21). Moreover, 5 products have anvil retouch, generating triangular cross sections. Like PDs, LDs are very homogeneous in thickness $(0.2-0.6 \mathrm{~cm})$ and wide $(0.4-1.1 \mathrm{~cm})$.

- 7 bipoints with backs: 6 bipoints with shaped segment backs (BPD12) and 1 bipoint with a trapezoidal back and trihedral spike (BPD31).
The same thicknesses $(0.3-0.4 \mathrm{~cm}$.) And wide (1-0.6 cm.) Are observed in the 7 products.

- 2 blades with truncated backs: 1 blade with an occluded truncated back (LDT11) and 1 blade with a double arched occluded back (LDT21).

- 4 bitroncatures, 3 of which are shaped segment bitroncatures (BT1) and 1 is an open trapezoidal bitroncature (BT32).

- 13 chisels: 12 simple chisels with one side (B11) and 1 chisel with side panels (B31).

The presence of debris or other size remains (ORT) was also noticed, composed by splinters (300), waste (524), chisel scraps (5) and trihedral prickles (3), which indicate that the lithic production space. These products are neither greatly weathered nor heat-altered, like the rest of the register. The raw material is consistent with the rest of the lithic register, dominated by flint, chalcedony and silicified shale. A large part of the waste is spent cores (95), correlating with the high degree of exploitation of the BN1G studied. As for the by-products of the chisels and microburins, they are consistent with the geometric microlites and chisels found in the deposit.

\section{The study of the raw material}

\section{Origin of the raw materials used for the Guenfouda lithic assemblage}

The rocks chosen for size belong to almost all geological eras:

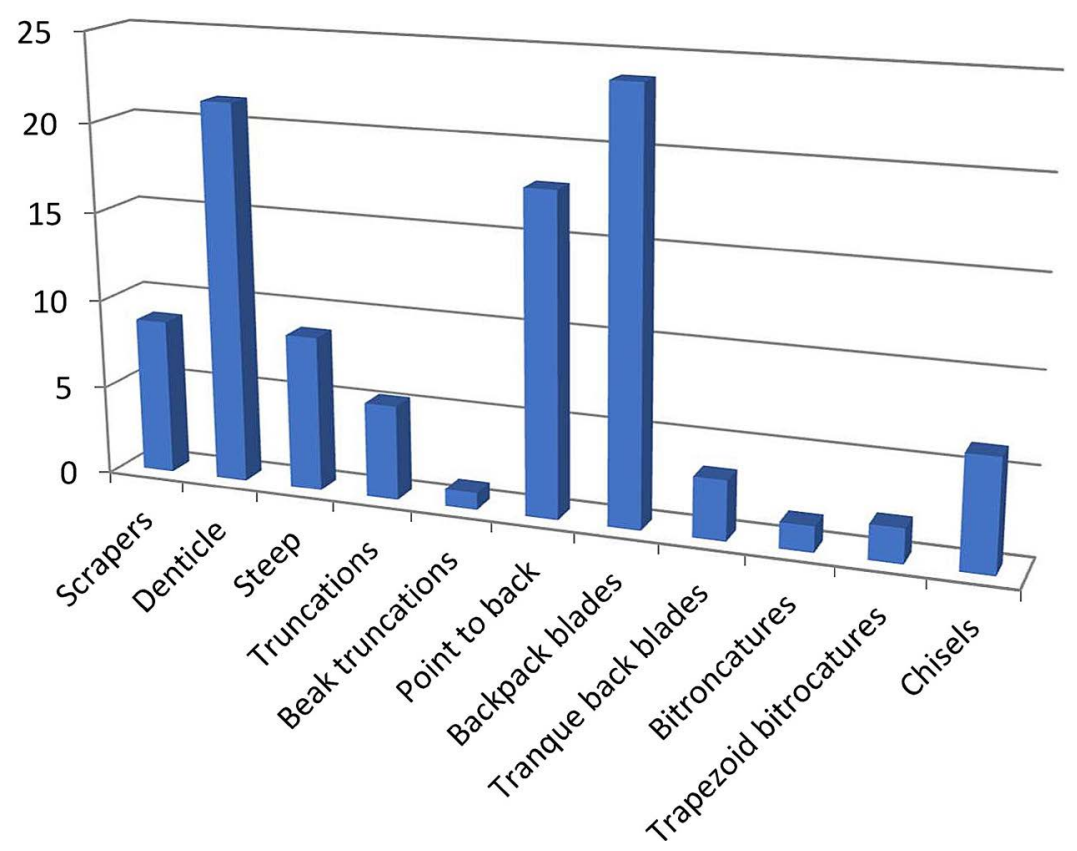

Figure 12. BN2G product (retouched artifacts) from Guenfouda 


\section{BN2G-G12 BN2G-G311}
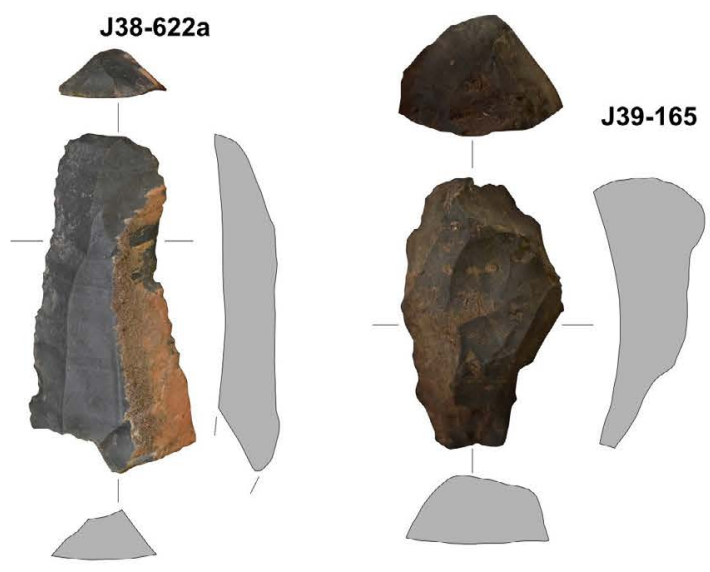

\section{BN2G-A1}

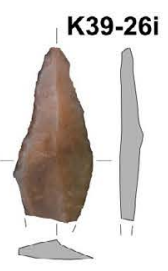

\section{BN2G-A2}
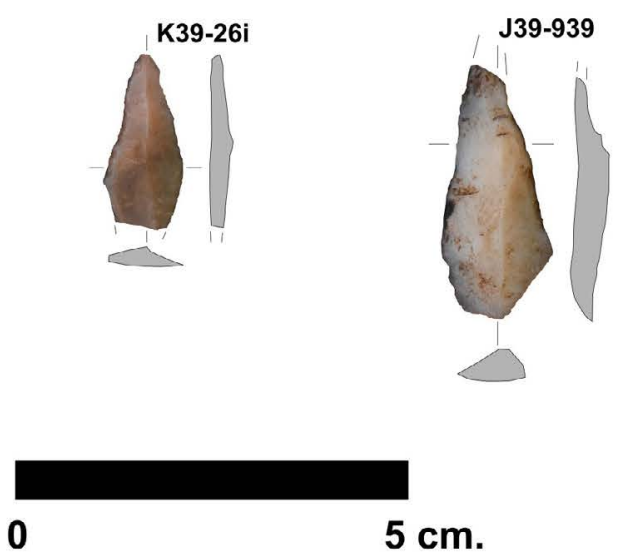
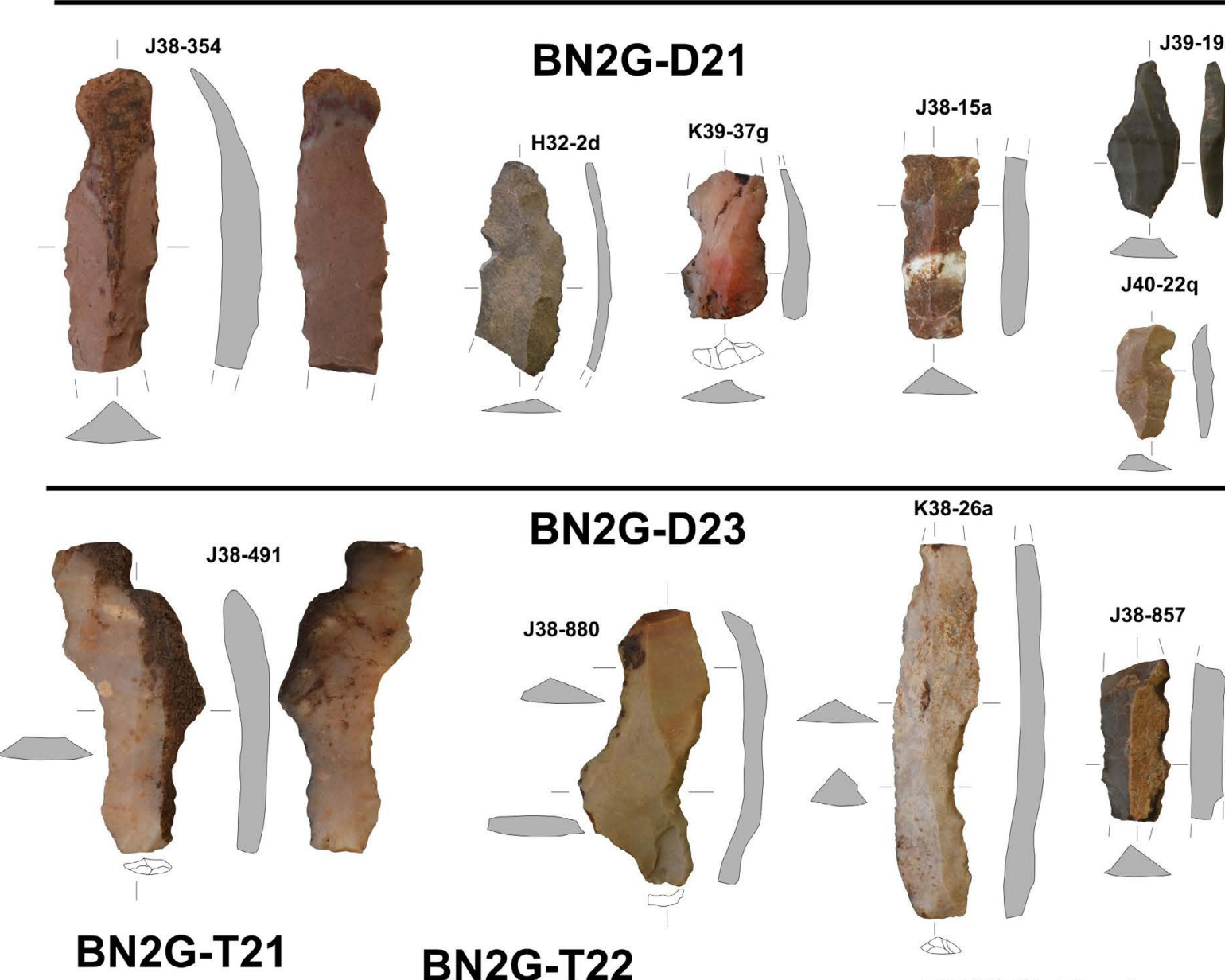

K39-28b
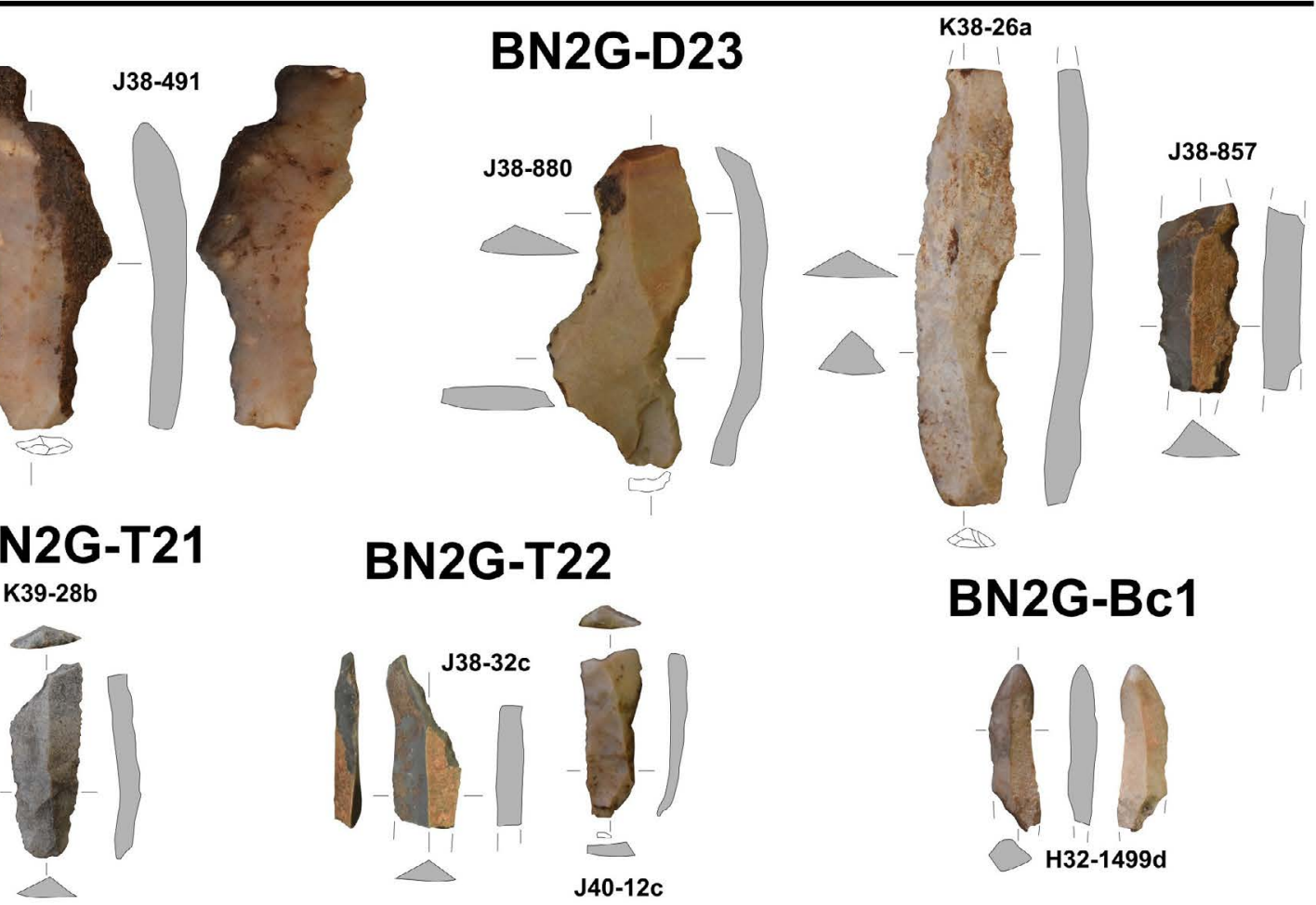

Figure 13. BN2G product (retouched artifacts) from Guenfouda (Almisas and Souhir) 


\section{BN2G-PD23}
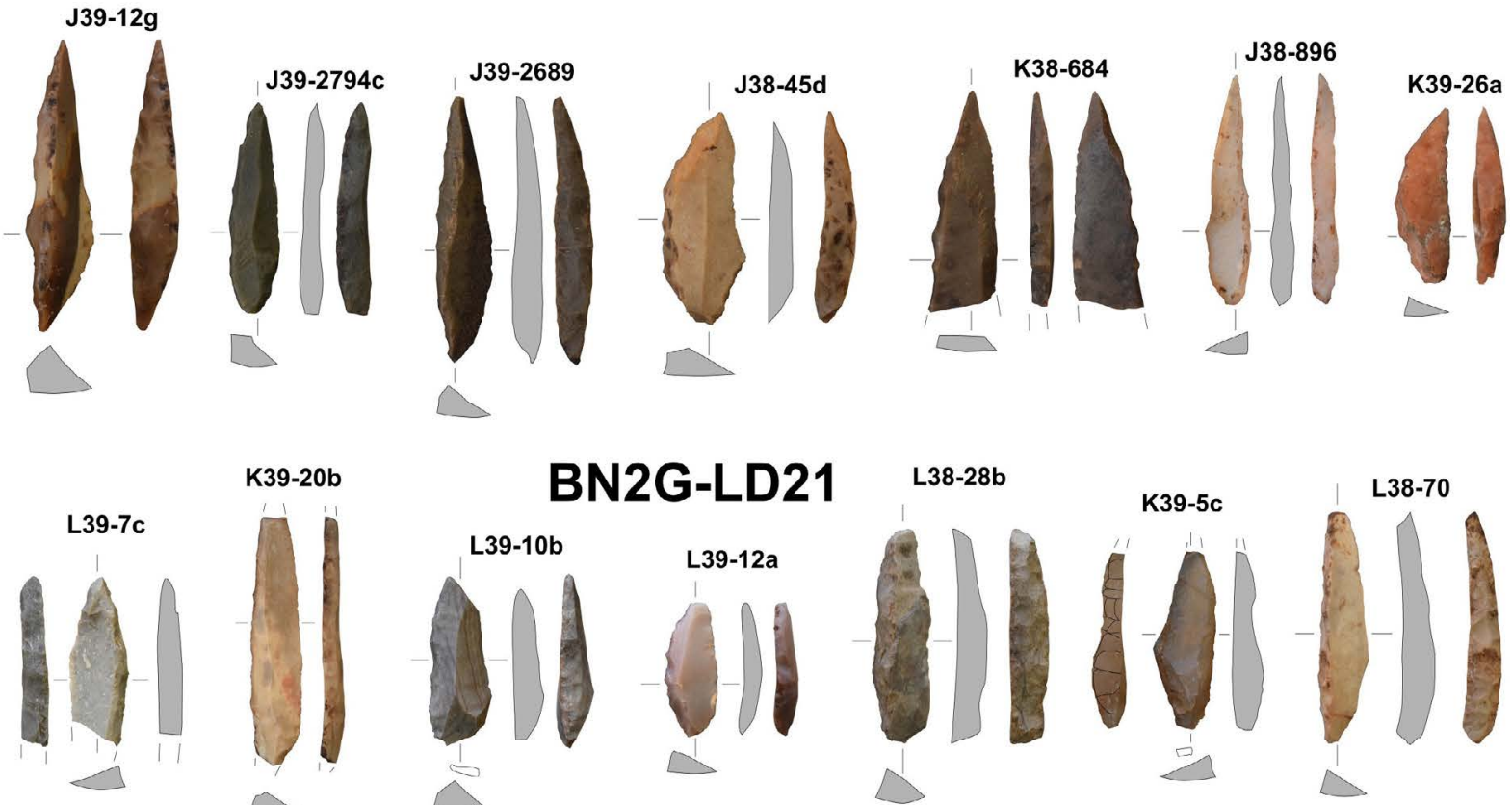

K39-20b
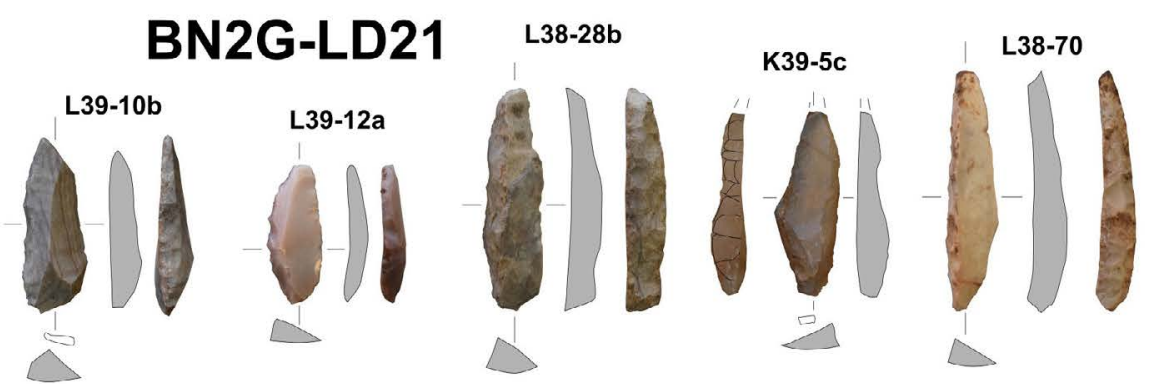

\section{BN2G-BPD12}
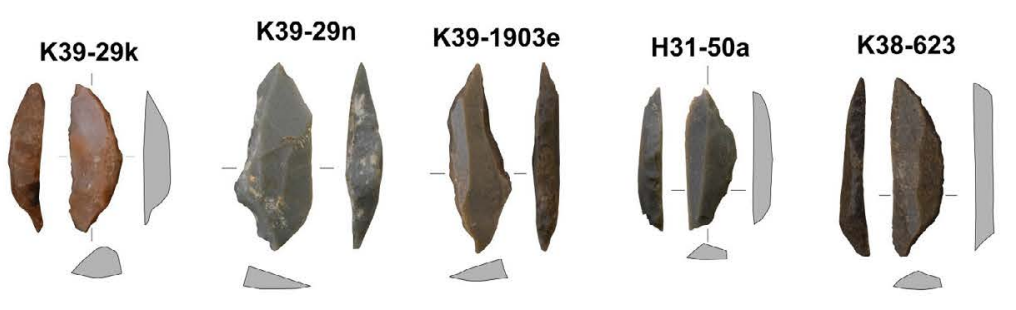

BN2G-BPDx31

\section{BN2G-BT1}

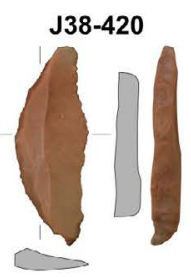

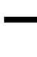

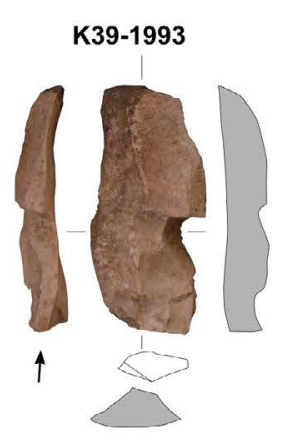

BN2G-BT32

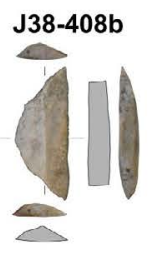

0

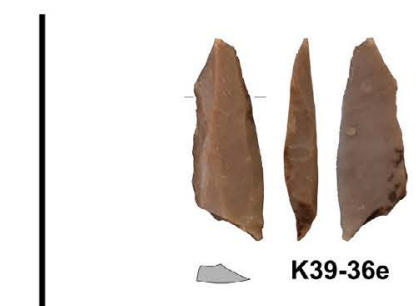


Table 1. Guenfouda lithic products

\begin{tabular}{|c|c|c|}
\hline TYPE & $\mathrm{N}$ & $\%$ \\
\hline BNG1 & 130 & 5,0544 \\
\hline Starting Knapping & 30 & 23,077 \\
\hline Unipolar & 45 & 34,615 \\
\hline Bipolar & 38 & 29,231 \\
\hline Polyhedric & 3 & 2,3077 \\
\hline Mulitopar Centipetal & 6 & 4,6154 \\
\hline Prismatique & 8 & 6,1538 \\
\hline Total 1 & 130 & \\
\hline $\mathrm{BP}$ & 1404 & 54,609 \\
\hline Cortical & 22 & 1,567 \\
\hline Semi-Cortical & 88 & 6,2678 \\
\hline Interne & 1092 & 77,778 \\
\hline Levallois & 4 & 0,2849 \\
\hline Blade & 114 & 8,1197 \\
\hline Crested & 84 & 5,9829 \\
\hline Total 2 & 1404 & \\
\hline ORT & 832 & 32,348 \\
\hline Microflakes & 300 & 36,058 \\
\hline Discards & 524 & 62,981 \\
\hline Burin spalls & 5 & 0,601 \\
\hline Trihedral point discards & 3 & 0,3606 \\
\hline Total 3 & 832 & 100 \\
\hline BN2G & 206 & 8,0093 \\
\hline Total 4 & 206 & \\
\hline TOTAL & 2572 & 100 \\
\hline
\end{tabular}

\begin{tabular}{|c|c|c|}
\hline TYPE & $\mathrm{N}$ & $\%$ \\
\hline BNG2 & & \\
\hline G11 & 7 & \\
\hline G12 & 4 & \\
\hline G31 & 3 & \\
\hline G312 & 2 & \\
\hline G322 & 2 & \\
\hline Scrapers & 18 & 8,737864 \\
\hline D11 & 2 & \\
\hline $\mathrm{D} 21$ & 26 & \\
\hline $\mathrm{D} 23$ & 16 & \\
\hline Denticle & 44 & 21,35922 \\
\hline A1 & 8 & \\
\hline $\mathrm{A} 2$ & 10 & \\
\hline Steep & 18 & 8,737864 \\
\hline $\mathrm{T} 21$ & 4 & \\
\hline T22 & 7 & \\
\hline Truncations & 11 & 5,339806 \\
\hline $\mathrm{BC} 1$ & 2 & \\
\hline Beak truncations & 2 & 0,970874 \\
\hline PD11 & 5 & \\
\hline PD21 & 1 & \\
\hline PD22 & 26 & \\
\hline PD25 & 5 & \\
\hline Point to back & 37 & 17,96117 \\
\hline LD11 & 6 & \\
\hline LD22 & 43 & \\
\hline Backpack blades & 49 & 23,78641 \\
\hline BPD12 & 6 & \\
\hline BPD31 & 1 & \\
\hline Tranque back blades & 7 & 3,398058 \\
\hline LDT11 & 2 & \\
\hline LDT21 & 1 & \\
\hline Bitroncatures & 3 & 1,456311 \\
\hline BT1 & 3 & \\
\hline BT32 & 1 & \\
\hline Trapezoid bitrocatures & 4 & 1,941748 \\
\hline B11 & 12 & \\
\hline B31 & 1 & \\
\hline Chisels & 13 & 6,31068 \\
\hline TOTAL & 206 & \\
\hline
\end{tabular}


For the Paleozoic, there are quartzites; phtanites, silicified green schists (sedimentary rocks metamorphosed in the facies of green schists), tuffites (volcano-sedimentary rock) and dacites (effusive rock);
For the Mesozoic rocks we find flint, chalcedony of the Trias (of vein origin in dolorites), lower Jurassic flint and Aalino-Bajocian limestone;

For the Cenozoic rocks we find the Basalts, the chalcedony of oued el Hay of the Quaternary.

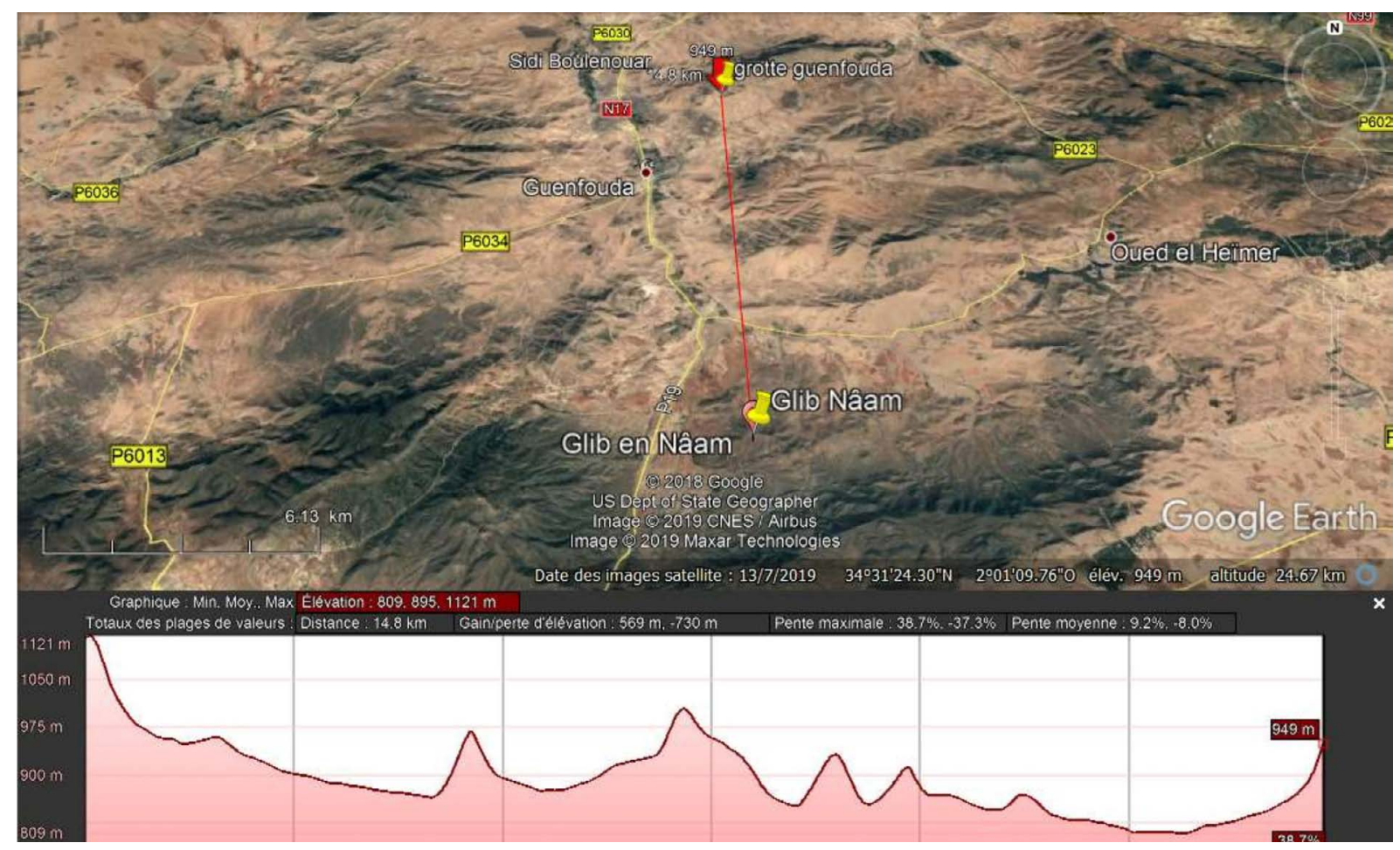

Figure 15. Glib Nâam buttonhole (Mount of Oujda)

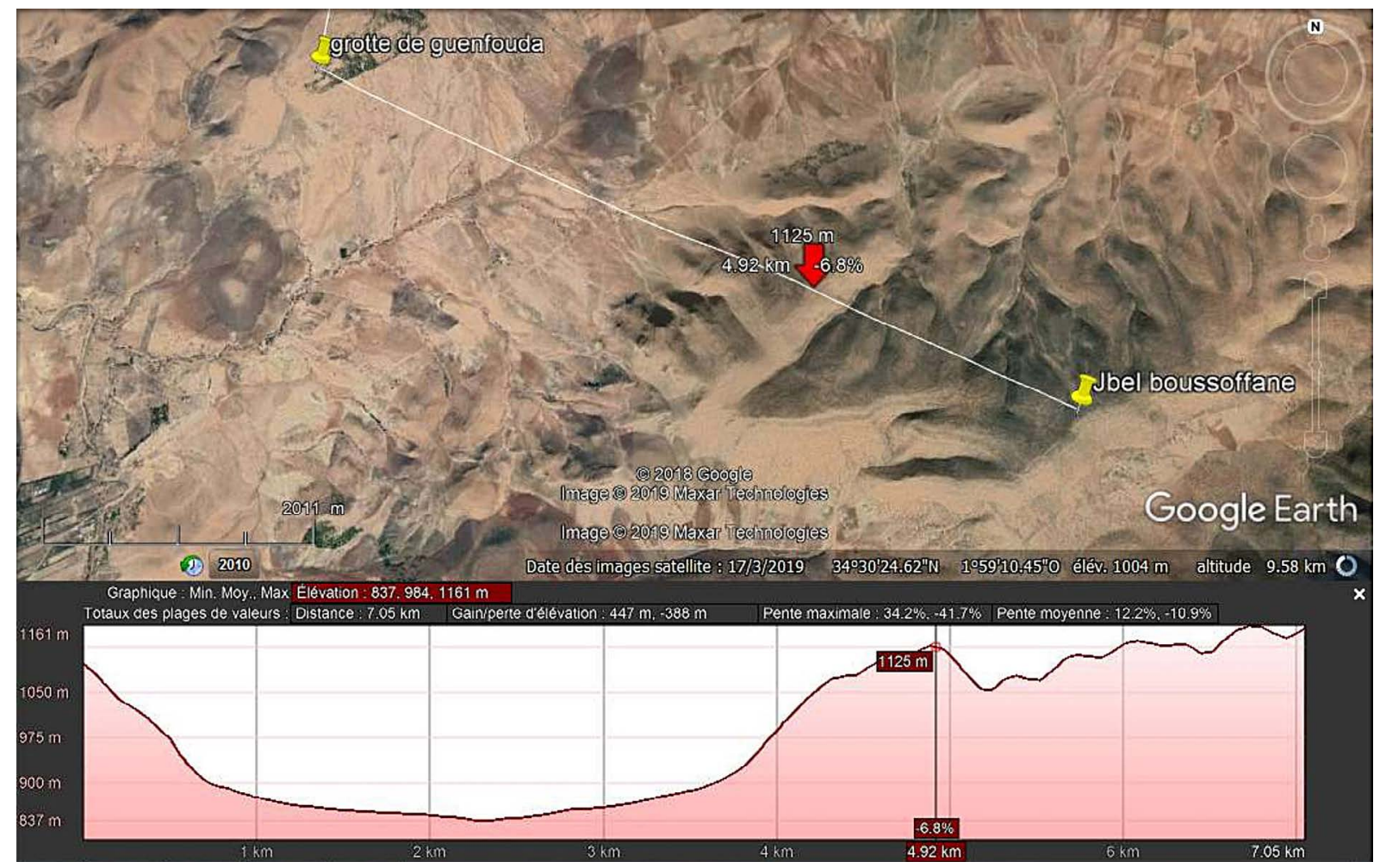

Figure 16. Jbel Boussouffane (Mount of Oujda) 


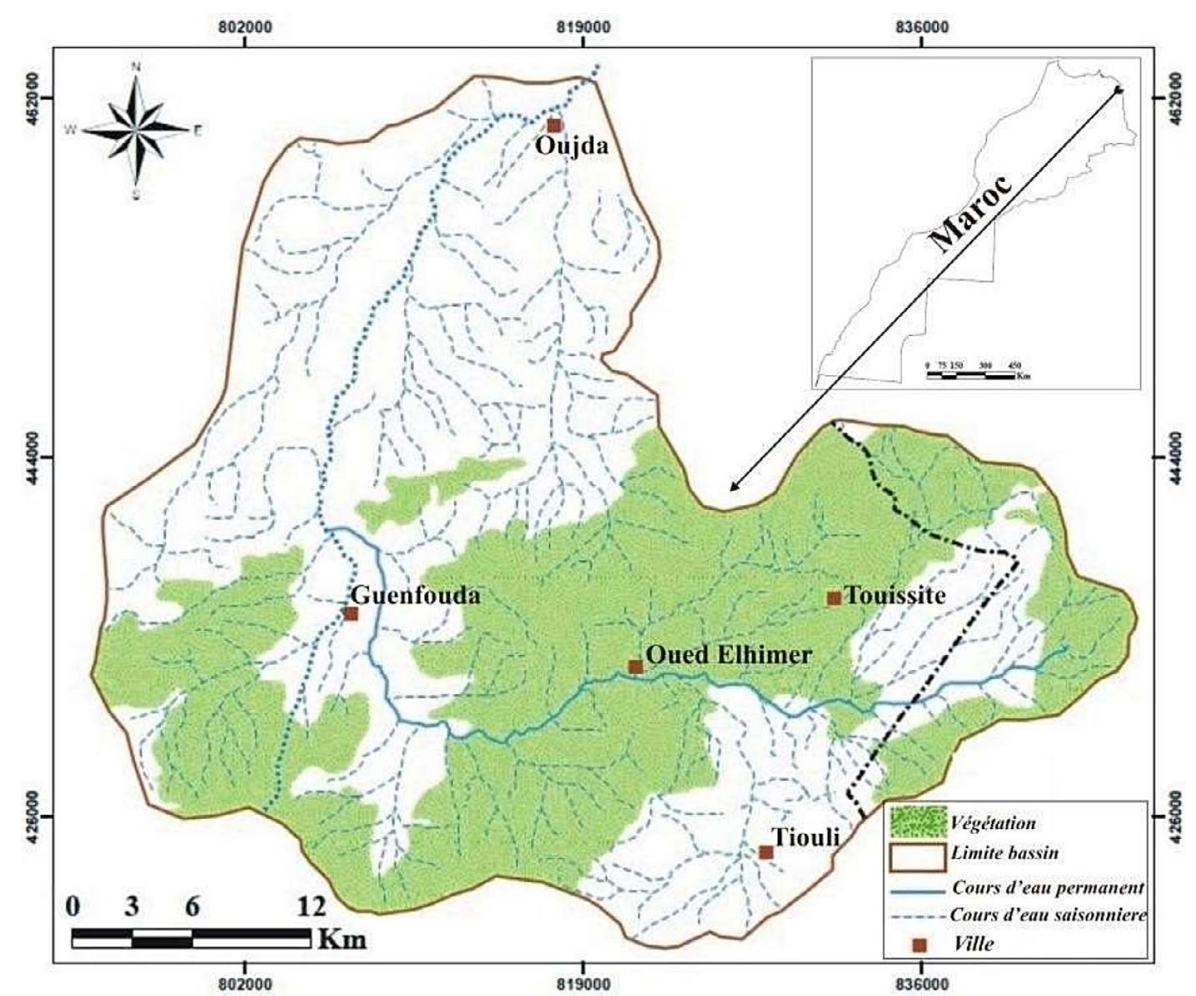

Figure 17. Location of the Oued Isly basin

The regions that supply these raw materials are the silicified green schists. Quartzites and tuffite come from the Glib Nâam buttonhole of the viseen upper $16 \mathrm{~km}$ from the cave to the south.
The phtanites and quartzites come from the buttonhole of Jbel Bousouffane in the Oujda mountains to the north, $10 \mathrm{~km}$ in front of the cave.

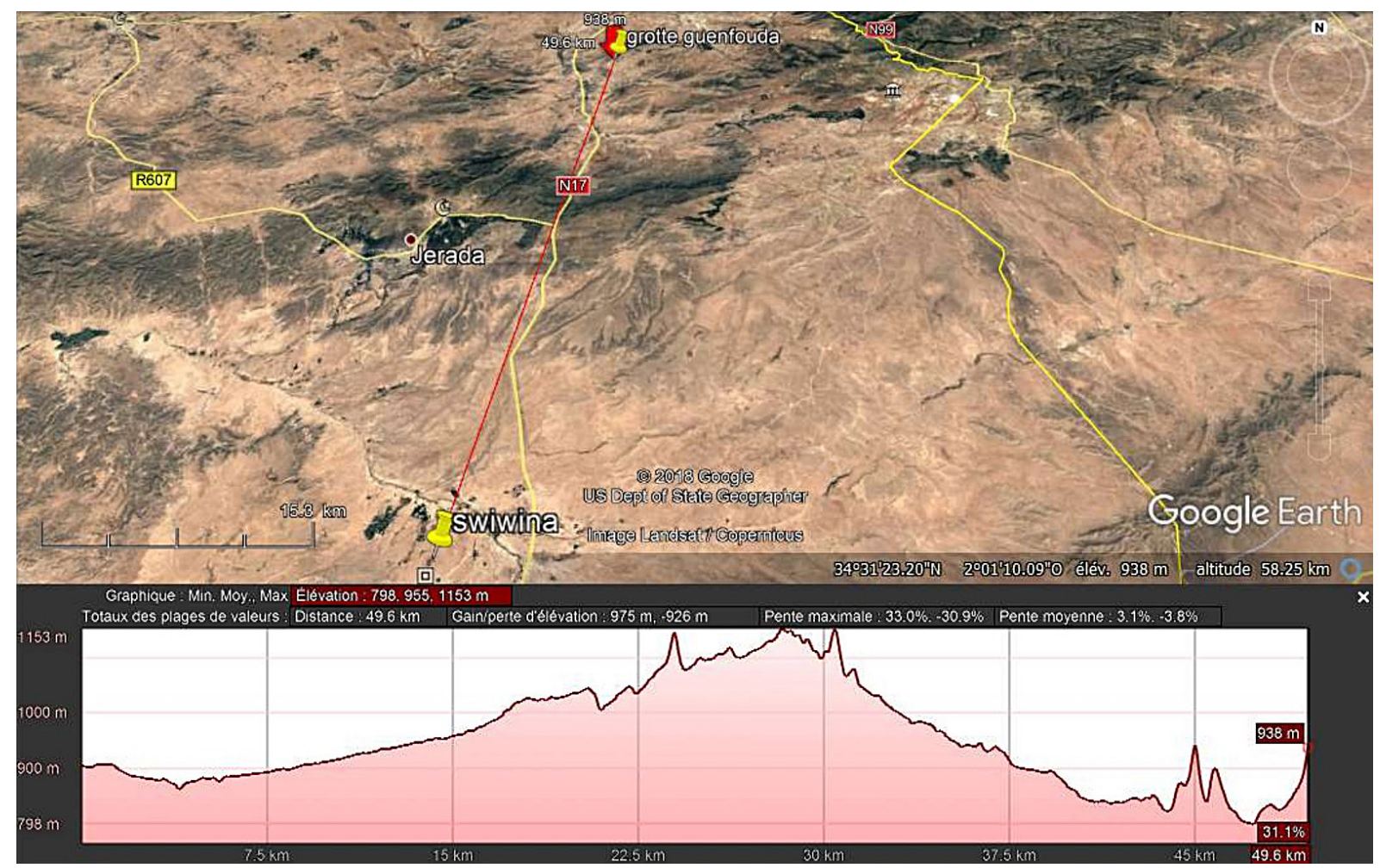

Figure 18. Swimina (Oued El hay basin) 
For the dacites outcrop on very weathered ground, it can only come from secondary grounds, in particular alluvial layers of wadis.

The study of drought sequences in the lsly Basin (East Morocco) [El Hafid D; et al. 2017, 87].

Phtanites are scarce on the lenses dating from the Silurian era. The flint and chalcedony of the Triassic come from different outcrops of the Oujda mountains. Limestone (Aalino-Bajocien) and basalt (Pllio-Quaternary) make up the cave. The chalcedony of oued El Hay is found on Swimina $60 \mathrm{~km}$ south of the cave, formed on lake limestone (silification).

\section{Distribution of raw materials in the Guenfouda lithic assemblage}

In Guenfouda, the most abundant types of lithics are flint, silicified green schist and chalcedony. They come from Paleozoic or Mesozoic (the Trias) lands of the Oujda mountains (Glib Nâam and Jbel Boussoufane), at distances between 10 and $30 \mathrm{~km}$. Others that are in the minority, such as limestone and basalt, are found near the site or in the valley of Wadi Isly. The use of the raw material is certainly linked to the quality of the rock, and perhaps to the difficulty of finding good materials to cut than to the quantity available. It should be noted that the chalcedony of Oued El
Hay, located about $60 \mathrm{~km}$ away, is poorly represented. This may be due to the distance between the procurement area and the site.

\section{Other archeological remains in C1 layer}

As it was already pointed out, the $\mathrm{C} 1$ layer not only reveals the lithic assembly, but other archaeological remains of which are analyzed here, i.e. the fauna, uncut lithic tools and pottery.

The study of malacofauna and fauna revealed the richness of the site and its archaeological potential [Bougariane, 2013; Aouraghe et al., 2010]. The identification of the fauna of Guenfouda [Bougariane, 2013: 44 et seq.], revealed the presence of domesticated species such as Capra hircus, Ovis aries, Capra / ovis or Canis lupus f. familiaris; but also wild species typical of the Moroccan Holocene: cattle (Bos primigenius, Alcelaphus buselaphus, Gazella sp. or Ammotragus lervia), reptiles such as turtles, herbivores such as Equus sp., suidae such as Sus scrofa; and lagomorphs like rabbit.

The uncut lithic tool is confirmed by a stone axe that highlights activities related to woodworking, and crushed stone tools, which in turn, can highlight activities related to the grinding of grains or minerals (Fig. 20).

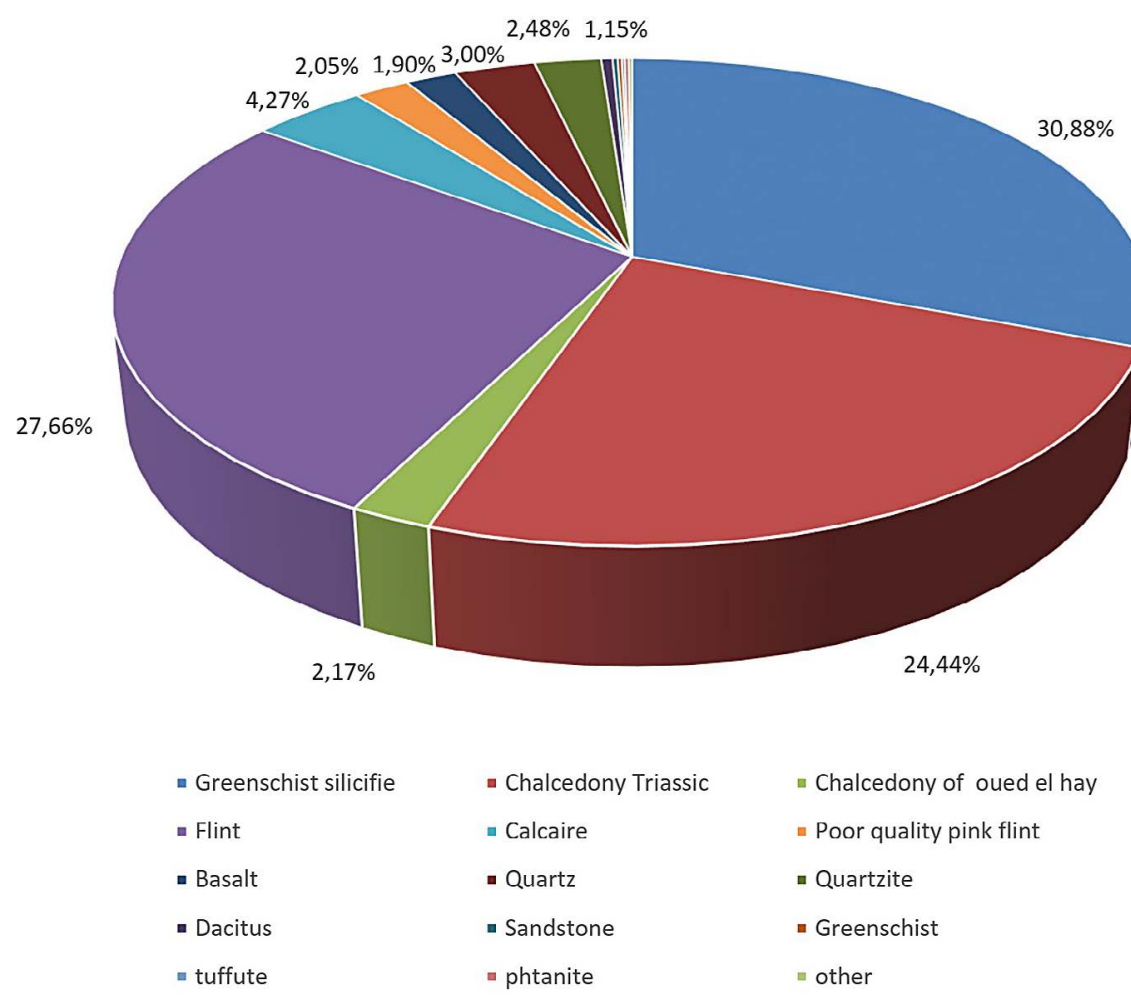

Figure 19. Distribution of raw materials in lithic material 

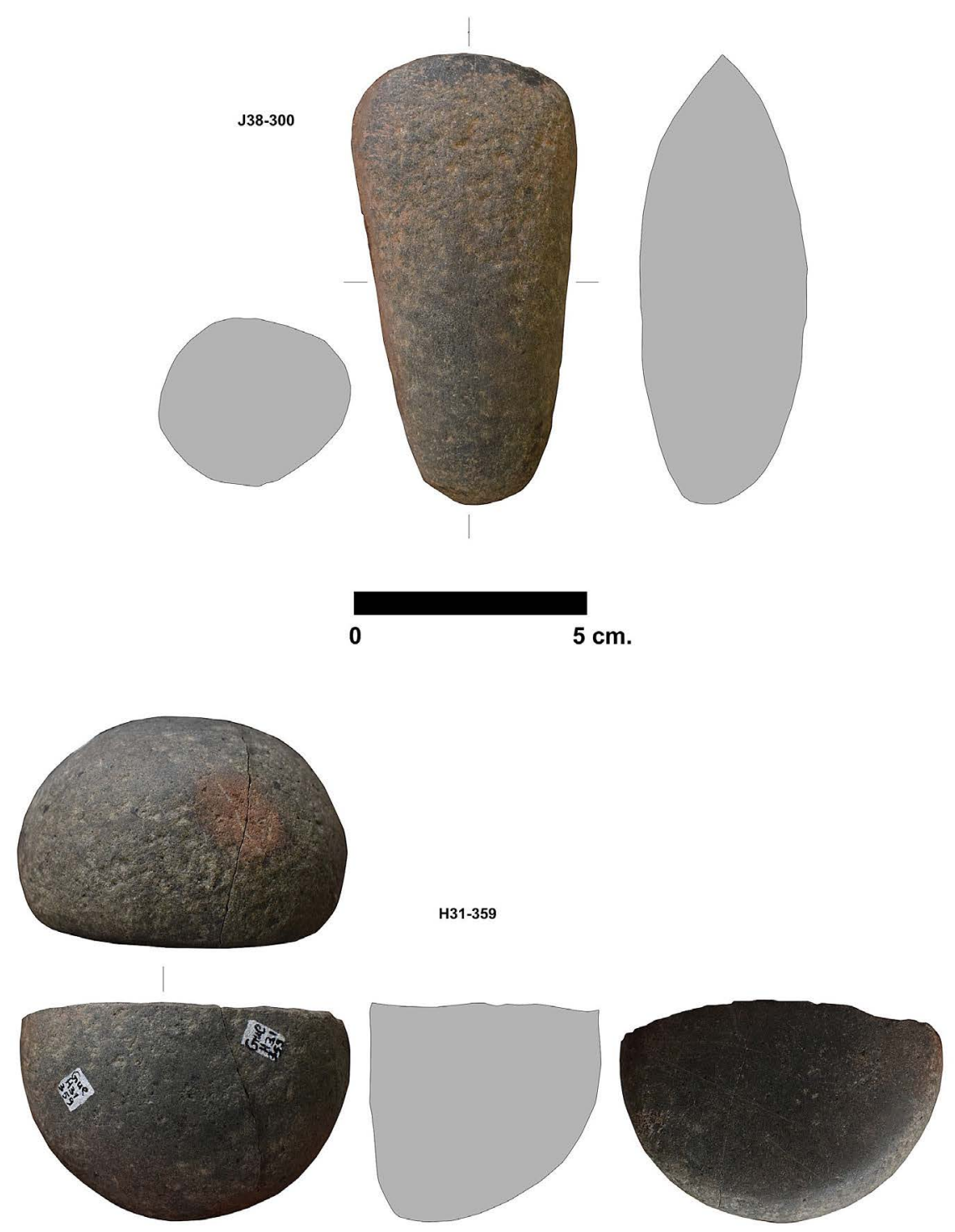

Figure 20. Polished ax and wheel from Guenfouda's level 1 (Almisas and Souhir)

In addition, 132 pottery scraps in layer 1 , which were really fragmented, were documented. Among these, 15 rims and 1 base were identified. No shape can be distinguished due to the high imposition of fragmentation. Regarding the technical aspects of production, this pottery has an irregular firing with predominance of reduction firing and a moderately abundant proportion of medium-large temperament. The surface treatment of shards is characterized by its softness, but one can also find polished and scraped surfaces.

The surface treatment is completed with decorations and other elements, such as two rims, each with a nipple. Incisions and impressions dominate the decoration techniques. Comb prints, generating ear and frieze shapes were found. Shell and scroll printing were also documented. The incision appears in linear shapes without much development. Finally, shreds with channeled decoration were documented. A conical base in this set should not be ignored, because of its similarity to those previously documented in the Neolithic of the region [Camps, 1974; Daugas et al., 2008] (Fig. 21).

\section{DISCUSSION}

In order to reach some conclusions, the pointed out characteristics of the $\mathrm{C} 1$ layer and the lithic assemblage must be discussed.

As it was shown, there is a predominance of local lithics such as silicified schists, flint and chalcedony of Trias in Guenfouda's C1 layer. These results are similar to those of Luc Wengler's studies [Wengler et al., 1989] of the Rhafes 
A

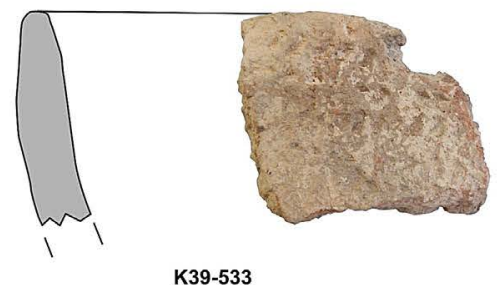

K39-533

C

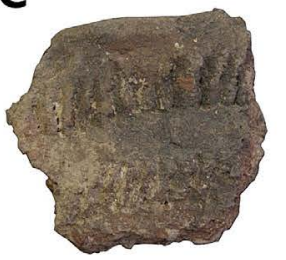

J38-814

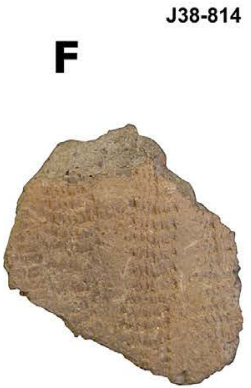

L38-957
D

$\mathbf{G}$

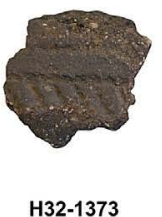

H32-1373

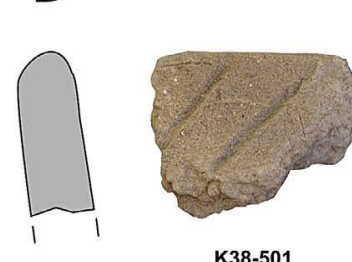

K38-501
B

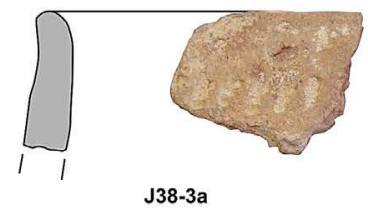

$\mathbf{E}$

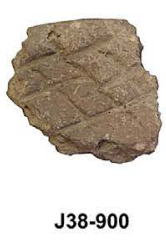

I

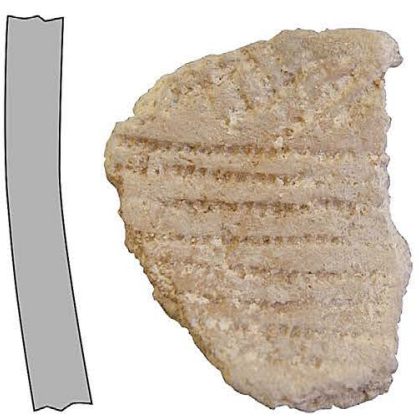

K38-538
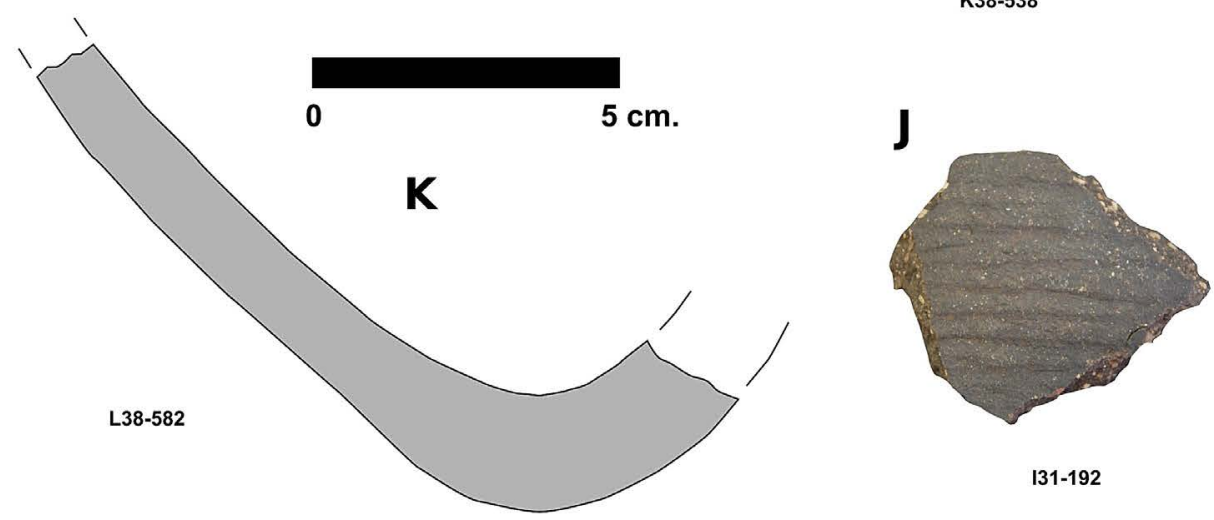

Figure 21. Pottery from level 1 of Guenfouda. A-C: Printing; D-E: Incision; F-I: comb printing; J: fluted; K: conical bottom ((Almisas and Souhir)

cave's lithics (15 km from Guenfouda). Future research and studies using archaeometric techniques should clarify this preliminary conclusion. A program of mineralogical, petrological and geochemical analysis of the lithic materials found on the site must be carried out to identify the sourcing strategies of the lithic materials.

The authors were able to document the entire production process of lithic knapping; also called the operating chain. The study of lithic assemblage clearly supports this by showing all the phases of lithic cutting activities (BN1G, BP, ORT and, BN2G). The presence of a large number of cores (BN1G) and waste cores (ORT-DES) in the assembly was reported. The presence of cortical and semi-cortical (BP-D and BP-SD) flakes is also significant. In addition, a significant number of cortical blisters and cortex in the dorsal aspect were counted within $23 \%$ of the positive bases. All of these points to an in-situ knapping activity pattern.

Regarding the technical characteristics of lithic technologies at Guenfouda, the analysis 
of Indirect Operative Technical Themes (ITOT) points to five techniques used to exploit the bases and cores: unipolar (1), bipolar (2), multipolar centripetal (3), polyhedral (4) and prismatic (5). These techniques are common in other Neolithic sites in northern Morocco (Almisas, 2018b). In Guenfouda, the cores, mainly bipolar and unipolar, revealed a clear relationship with the positive bases, which are very small in size and have a moderate proportion of laminae. The retouched products (BN2G) are composed of a large set of tools that are similar to other already found materials in other sites of the regional Neolithic: notches and serrated lamellae (D) backed (LD) and backed-points (PD). These can be associated with hunting and cutting activities. Although marginal, the presence of the microburin technique and microlithic products such as LDT can be reported; it can be associated with the use of projectiles in a strategic area for hunting activities [in Aouraghe et al., 2014]. This hypothesis can only be confirmed by the development of functional research projects on the site.

Finally, the problem of the pressure blades was noticed. Some of these products were found, but without their operational sequencing or operational chain: essentially, the absence of blade cores oriented towards the use of this technique. As a hypothesis, it can be suggested that there could be a circulation of already elaborate or semi-elaborate tools, similar to what has been proposed for other Neolithic sites in Morocco [Bailloud y Mieg de Boofzheim, 1964; Almisas, 2018b].

In relation to the dating of the site, due to the lack of absolute dating, a regional comparison is mandatory in order to insert the Guenfouda $\mathrm{C} 1$ layer in a relative chronology. The only wellstudied site in the eastern region with a Neolithic layer ( 1 level) is the Rhafas cave [Wengler et al., 2001]. The Neolithic level of Rhafas is dated from the passage from the $\mathrm{V}$ to the IV millennium $\mathrm{BC}$ : 4314-3772 cal 2 $\sigma$ BC (Gif 6185) [Wengler, et al., 1994: 126]. New dating of level 1 sediments with the OSL technique, carried out under the direction of Abdeljalil Bouzouggar (INSAP), corroborates the fact that level 1 is not older than the 6th millennium BCE: $7800 \pm 600$ BP (L -EVA-1210) [Doerschner et al., 2016]. The archaeological assemblage at this level is made up of scraps of pottery, fauna, a stone ax, bone tools, scraps of ostrich eggs and, in particular, lithic industry. This lithic assemblage was studied [Almisas, 2018b] and some similarities with that of Guenfouda can be identified. It was performed, not only for its technology but also because of the typology and the raw material used [Almisas, 2018b].

Regarding Guenfouda pottery, it was noted that the comb decorations are similar to those of the El Kiffen type [Bailloud and Mieg el Boofzhiem, 1964], considered pre-campaniform, and associated with the Middle Neolithic [Daugas et al., 1989].

In general, the analysis of Guenfouda's C1 layer's products: knurls, polishing, incise pottery and lithic industry performed here directs us towards its association with the regional Middle Neolithic, specifically the 4th millennium BC.

Finally, the importance of the deductions made from the social activities and the nature of the society which generated this archaeological record must be underlined [Bate, 1998]. Lithic industry, such as pottery, faunistic and botanical remains, etc. informs us about the human activities of prehistoric groups and helps us to reconstruct their social organization. Far from being able to make an integral and solid study of prehistoric Neolithic society, due to the limited archaeological dates available in the region, our objective has been to discuss the ideas already published on these societies.

The activities that can be deduced from the documented products relate to hunting, harvesting, pastoral and agricultural activities. Although the latter are weaker, the pruning activities of the forest mass, documented by the presence of polished axes, together with the spread of domesticated plant species throughout North Africa strengthens this possibility. In order to better understand the activities of these groups, it would be essential to find and excavate open-air deposits, privileged areas of habitat and work of these groups around the entire Mediterranean. As it was already demonstrated [Almisas, 2018b], it is in open-air sites where Neolithic groups develop pastoral and agricultural practices.

Social practices, well-documented in the investigated site and others in the region (i.e Rhafas), involve animal domestication (marking the presence of dogs), which informs us about the development of a pastoral way of life, perhaps semi-sedentary, in this region of the Middle Neolithic, and with great historical continuity (Fig. 22). This idea has already been defended by Luc Wengler [Wengler et al., 1989].

Our hypothesis on the characterization of the Neolithic groups is that they were in a process of a deep social transformation, though very contradictory. This process is the result of the dissolution of 


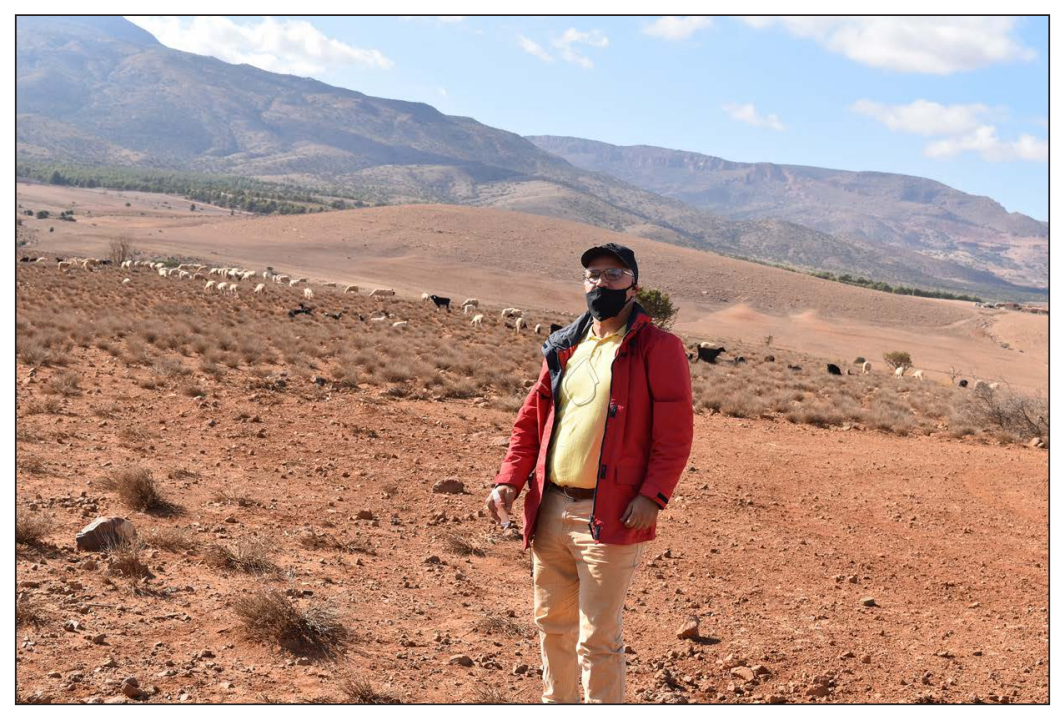

Figure 22. Pastoral activities in the vicinity of the Guenfouda cave (Year 2020)

hunter-gatherer groups and the gradual emergence of tribal societies characterized by a new form of organization, production and reproduction.

\section{CONCLUSIONS}

The cave of Guenfouda, in eastern Morocco has a great value for North African archeology. The site, already being excavated, offers us a sequence which must be precise and well-dated. However, its upper level corresponds to a Neolithic occupation. A sample of the level 1 lithic industry was studied. The homogeneity of the assemblage is clear and shows that the entire lithic production process took place on the site by prehistoric groups, as it was mentioned, with only one exception: the pressure blades. The exploitation of local raw materials, such as silicified shale, flint or chalcedony, and the application of cutting techniques oriented towards the production of lithic bases (BP) for the production of retouched products in series (notches and denticulates, but mostly backed points and sipes), are some of the results of our research.

The study of pottery shreds from the Neolithic level, and its comparison with the site near Rhafas, allow suggesting the dating of Guenfouda to the fourth millennium BC. Moreover, the site offers the evidence to infer the activities of hunting and domestication of animals, but also the consumption of plants and plant resources. The existence of a pastoral way of life inserted in tribal social formation within the prehistoric groups that lived in the cave of Guenfouda and its surroundings in the Neolithic period was underlined.
New studies must be carried out to better understand the nature of the site: petrological and wear studies of its lithic assemblage, palynological studies of the sediments, absolute dating and territorial studies for the location of new sites. All these studies should be developed to complete the information of prehistoric societies of eastern Morocco and to confirm or reject the hypotheses discussed in this article.

\section{Acknowledgments}

Thanks to our students: Mourad Farkouch and Ahlam Belchgar who help us in the washing of tools.

\section{REFERENCES}

1. Aouraghe H., Gagnepain J., Haddoumi H., El Hammouti K., Ouchaou B., Bailón S. Mestour B., Oujaa A., Bouzouggar A., Billy A. 2008. La grotte préhistorique de Guenfouda, Maroc Oriental: les premiers résultats (fouilles 2004-2007). Actes de la quatrième Rencontre des Quaternaristes Marocaines (RQM4), 299-320.

2. Aouraghe H., Agustí J., Ouchaou B., Bailón S., López-García J.M., Haddoumi H., El Hammouti K., Oujaa A., Bougariane B. 2010. The Holocene vertebrate faune from Guenfouda site, Eastern Morocco. Historical Biology, 22(1-3), 320-326.

3. Aouraghe H., Haddoumi H., El Hammouti K., Oujaa A., Bougariane B. 2014. La grotte préhistorique de Guenfouda, Maroc Oriental: dix ans de recherches archéologiques (2004-2014). Rapport de fouille: mission archéologique Guenfouda", En Oujaa, Aïcha; Boudad, Larbi; Ouchaou, Brahim (Dir. Sci.): 
Géosciences, environnement et patrimoine de part et d'autre du Détroit de Gibraltar. Actes de la sixième Rencontre des Quaternaristes Marocaines (RQM6), Tanger, 15-17 Novembre 2011, 249-266.

4. Bagolini B. 1968. Ricerche sulle dimensioni dei manufattiliticiprehistorici non ritoccati. Anna Lidell Universitá di Ferrara XV (I), 10, 195-219.

5. Almisas S. 2018a. Potencialidades y limitaciones de la Arqueología Social en los estudios prehistóricos. El caso de los grupos tribales neolíticos en Marruecos. En Agudo Pérez L., Duarte C., García Escárzaga A. Geiling J.M., Higuero Pliego A.; Núñez De La Fuente, Sara; Rodríguez Santos, Fco. Javier ; Suárez Revilla, Roberto (Eds.): Actas de las IX Jornadas de Jóvenes en InvestigaciónArqueológica. Santander 8-11 de junio de 2016, 437-442.

6. Almisas S. 2018b. Las sociedades tribales neolíticasdellitoralafricano de la Regióngeo-históricadelEstrecho de Gibraltar. Tesis Doctoral inédita. 2 Tomos. Universidad de Cádiz.

7. Almisas S. 2019. Mouvements de population et migrations dans les groupes tribaux marocains. Approche historique. En Ramos Muños, José; Otte, Marcel; Vijande Vila, Eduardo (Eds.): Les Migrations entre Méditerranée et terre promise. Ocupaciones de la regióngeohistóricadelEstrecho de Gibraltar porsociedadesprehistóricas y de la Antigüedad. Movilidades de población, relaciones y contactos. Vol. 1., Universidad de Cádiz, 153-167.

8. Bailloud G. Mieg De Boofzheim P. 1964. La nécropole néolithique d'El Kiffen, près des Tamaris (province de Casablanca, Maroc), Lybica, 13, 95-171.

9. Bate L.F. 1998. El proceso de investigación en Arqueología. Crítica, Barcelona.

10. Bougariane B. 2013. Les vertébrés du Pléistocène terminal-Holocène de quelques sites marocains: paléontologie, taphonomie et archeozoologie. Thèse Docteur ès sciences, spécialité géologie, Université Moulay Ismaïl, Meknès, Maroc.

11. Camps G. 1974. Les civilisations préhistoriques de l'Afrique du Nord et du Sahara. Doin, París.

12. Carbonell E. Rodríguez X.P. 2002. El sistemaLògicAnalític: origen, desenvolupament i perspectives de future. Cota Zero, 17, 106-116.

13. Daugas J.P., El Idriss A., Ballouche A., Marinval P., Ouchaou B. 2008. Le Néolithique ancien au Maroc septentrional: données documentaires, sériation typochronologique et hypothèses génétiques. Bulletin de la Société préhistorique française, 105(4), 787-812.
14. Daugas J.P., Raynal J.P., Ballouche A., Occhietti S., Pichet P., Evin J., Texier J.P., Debenath A. 1989. Le Néolithique nord-atlantique du Maroc: premier essai de chronologie par le radiocarbone. Comptes rendus de l'Académie des Sciences de Paris, 308(2), 681-687.

15. Doerschner N., Fitzsimmons K.E., Ditchfield P., Mclaren S.J., Steele T.E., Zielhofer C., Mcpherron S.P., Bouzouggar A., Hublin J.J. 2016. A new chronology for Rhafas, northeast Morocco, spanning the North African Middle Stone Age through to the Neolithic. Plos One. DOI: 10.1371/journal.pone.0162280

16. Laplace G. 1973. La typologie analytique et structurale : Base rationnelle d'étude des industries litigues et osseuses. Banques de donnés archéologiques. Colloques nationaux C.N.R.S, 932, 91-143.

17. Lubell D. 2004. Are land snails a signature for the Mesolithic-Neolithic transition?, Documenta Praehistorica, 31, 1-24.

18. Ramos M.J., Bernal Casasola D., Vijande Vila E. Cantillo J.J. (Eds. científicos) 2013a. El abrigo y la cueva de Benzú. Memoria de los trabajos arqueológicos de una década en Ceuta (2002-2012). Ciudad Autónoma de Ceuta, Servicio de Publicaciones de la Universidad de Cádiz.

19. Vargas I. 1990. Arqueología, Ciencia y Sociedad. Editorial AbreBrecha, Caracas.

20. Vijande E. 2015. Sociedades neolíticas en la Cueva de Benzú. Instituto de EstudiosCeutíes, Ceuta.

21. Wengler L. 1990. Économie des matières premières et territoire dans le Moustérien et l'Atérien maghrébins. Exemples du Maroc Oriental, L'Anthropologie, 94(2), 335-360.

22. Wengler L., Delibrias G. Michel P. Vernet J.L. 1989. Sites néolithiques du Maroc oriental: cadre chronologique, archéologie et milieu naturel", L'Anthropologie, 93(4), 507-534.

23. Wengler L., Vernet J.L., Michel P. 1994. Evénements et chronologie de l'Holocène en milieu continental au Maghreb. Les données du Maroc oriental”, Quaternaire 5(3-4), 119-134.

24. Wengler L., Wengler B., Brochier J., El Azzouzi M., Margaa A., Mercier N., Valladas H. 2001. La grotte du Rhafas (Maroc Oriental) et les recherches sur le paléolithique moyen. Actes des premiers Journées Nationales d'Archéologie et du Patrimoine. Préhistoire, $1,67-81$.

25. Study of Drought Sequences In The Ilsly Basin (East Morocco). El Hafid D.L., et al. 2017, pp. 87. 